Egyptian Journal of Aquatic Biology \& Fisheries

Zoology Department, Faculty of Science,

Ain Shams University, Cairo, Egypt.

ISSN $1110-6131$

Vol. 25(1): 983 - 1015 (2021)

www.ejabf.journals.ekb.eg

\title{
Aluminum, Chromium and Manganese in Sediments of Bahr Shebeen Nilotic Canal, Egypt: Spatial and Temporal Distribution, Pollution Indices and Risk Assessment
}

\author{
Elsayed A. Khallaf ${ }^{1^{*}}$, Mohammad M.N. Authman ${ }^{2}$ and Alaa A. Alne-na-ei ${ }^{1}$ \\ ${ }^{1}$ Zoology Department, Faculty of Science, Menoufia University, Shebeen Alkoom, Egypt \\ ${ }^{2}$ Hydrobiology Department, National Research Centre, 33 EL Bohouth St. (Former EL Tahrir St.), \\ Dokki, P.O. 12622, Giza, Egypt \\ *Corresponding author: ekhallaf@yahoo.com
}

\begin{abstract}
ARTICLE INFO
Article History:

Received: Jan. 3, 2021

Accepted: Feb. 26, 2021

Online: Feb. 28, 2021
\end{abstract}

Keywords:

Aluminum,

Chromium,

Manganese,

Sediments,

Nile Canal,

Egypt.

\section{ABSTRACT}

The distribution of aluminum (Al), chromium $(\mathrm{Cr})$, and manganese (Mn) in Bahr Shebeen Nilotic Canal (BSC) sediments were studied during the period from September 2014 to December 2015, at different selected sites (S1, S2, and S3) over the BSC at Shebeen Alkoom City, Menoufia Province, Egypt. Spatially, the levels of $\mathrm{Al}$ and $\mathrm{Mn}$ at different sites are arranged as follows: Site S1>Site S3>Site S2, whereas Cr levels were found to be in the following arrangement: Site S1>Site S2>Site S3. Seasonally, Al concentrations levels followed the order of summer> winter> autumn>spring, whereas the $\mathrm{Cr}$ and $\mathrm{Mn}$ levels were arranged in the order of winter> autumn>spring >summer. The different pollution indices of sediment and sediment quality guidelines (SQGs) showed that the BSC has uncontaminated, to low/or moderately contaminated sediments. Such occurrence might be related to biologically harmful health influences to the sediment-dwelling biota. The humans' hazard index $(\mathrm{HI})$ values for adults were greater than one; therefore, there were chances of having non-cancer risk for all studied metals on adult health through dermal contact exposure. However, $\mathrm{Cr}$ value is considered a carcinogenic risk, since its index (CRI) is more than the threshold level, designating that exposed adult humans are facing that risk. Finally, it is recommended that untreated wastes should be prohibited to reduce metal pollution.

\section{INTRODUCTION}

Heavy metals (HMs) were reported as dangerous contaminants for aquatic environments as a result of their persistency, bio-magnification, and bio-accumulation in the food chains, and toxicity effects on living organisms (Oyewumi et al., 2017; Khallaf et al., 2018a; Bing et al., 2019; Xia et al., 2020). The presence of domestic and industrial discharges, in addition to distributed agricultural inputs, could influence the aquatic environments, leading to the elevation of the potentially toxic element concentrations (Soliman et al., 2018; Bibi et al., 2020). The HMs pollution increasing has substantial adverse effects on invertebrates, fish, and human health (Yi et al., 2011; Rodríguez Martín et al., 2015; Proshad et al., 2018). They were partitioned 
among various components of the aquatic environment (water, biota, suspended solids, and sediments) (Shakweer and Abbas, 2005). As soon as they were drained to water sources, they became adsorbed on the sediment particles and accumulated in higher levels (Loska and Wiechuła, 2003). It is evident that about 99\% of the HMs in the aquatic ecosystems are transferred eventually to the bottom sediment (Peng et al., 2009; Goher et al., 2019).

Sediments; in the fluvial environments; can be contaminated by numerous types of harmful matters and HMs (Proshad et al., 2019). Sediments had been known as a ready sink or storage of contaminants, including HMs, where they accumulate according to the pollution level (Muohi et al., 2003; Abdel-Satar, 2005; Xia et al., 2020). HMs concentrations in sediments are influenced by natural factors such as natural erosion, flow changes, benthic agitation, rocks weathering, etc. Besides, anthropogenic factors as atmospheric deposition, traffic emissions, terrestrial runoff, disposal of liquid effluents, agricultural runoff and fertilizer leaching, industrial wastewater discharge, and sewage discharge, etc. (Islam et al., 2014; Iqbal et al., 2016; Khallaf et al., 2018a; Proshad et al., 2019; Bibi et al., 2020). Also, the HMs accumulation from water to sediment is linked to many external ecological factors. These are $\mathrm{pH}$ value, ionic strength, Eh, the level and type of inorganic and organic ligands, the possible adsorption surface area induced by the grain size distribution variation, and anthropogenic input (Davies et al., 1991). In the aquatic ecosystem, sediments can subsequently act as a potential contaminants secondary source (Yu et al., 2008; Bai et al., 2011; Lin et al., 2020). Because of chemical plus physical disorders, contaminants as HMs in sediments may be liberated into the water column, which implies that the sediments act as an essential sink and a long term release agent of HMs into the ecosystem even long after the initial input, which is of great importance for the aquatic system safety (Bing et al., 2019). Sediments were used to detect insoluble pollutants and demonstrate the water system quality (Karthikeyan et al., 2007; Lakshmanasenthil et al., 2013). Sediment's HMs analysis enabled detecting contaminants that perhaps either at low levels or absent in the aquatic medium (Binning and Baird, 2001). So, the study on HMs in surficial sediments were found to give essential understandings into elemental pollution and related hazards to protect the aquatic environment (Iqbal et al., 2016). The riverine sediments provided preferable documentation to evaluate the pollution and probable ecological hazard of HMs in the aquatic ecosystem, and indicated both spatial and temporal trends of contaminants (Bing et al., 2019; Tan and Aslan, 2020). So, the sediment's HMs distribution analysis near inhabited regions could be used to examine anthropogenic influences on environments and help evaluate hazards caused by the wastes releases of humans (de Mora et al., 2004; Zheng et al., 2008; Yi et al., 2011). Moreover, investigation of HMs in sediments of water environments is a substantial necessity to realize their influences on water and living organisms (Black and Williams, 2001; Elsayed et al. 2015, 2001; Ho and Hui, 2001). 
So, the aim of the current work was as follows: (1) to explore the spatially and seasonally variations of the $\mathrm{HMs}(\mathrm{Al}, \mathrm{Cr}$, and $\mathrm{Mn}$ ) concentrations in the sediment samples collected from different sites of Bahr Shebeen Canal (BSC), Egypt; (2) to compare HMs concentrations in the sediment of BSC with those in other various Egyptian areas; (3) to compare HMs concentrations with the recommended international permissible limits and sediment quality guidelines; (4) to evaluate and assess HMs pollution level, potential ecological risk and the carcinogenic and noncarcinogenic human health risk of HMs in the sediment of BSC.

\section{MATERIALS AND METHODS}

\section{Study area}

Bahr Shebeen Canal (BSC), located in the delta originating from a major canal (Alrayah Almenoufi) of Egypt (Fig. 1), represents a vital fishery source and used for irrigation. It extends for about $80 \mathrm{Km}$ passing through Menoufia, Gharbia, and Dakahlia governorates. It is an important, semi-independent ecosystem (30 m wide and 2-3 m deep) from the Nile (Khallaf and Authman, 1992), BSC is surrounded by various villages, two major cities, and cultivated lands. Due to human interference (shore protection works), shore plants are rare, especially near towns, and on shores, macrophytes are prevalent (Khallaf, 2002). No submerged plants are noticed during the water closure (embankment), which occurs in winter every year from 15 January to 15 February. The canal's bottom consisted mainly of silt, and sides/margins were regular and muddy (Sheir, 2018).

\section{Sediment sampling and pretreatment}

Twenty-three surface bottom sediments $(0-10 \mathrm{~cm})$ samples, during the period from September 2014 till December 2015, were collected from 3 main sites (S1, S2, and S3) along several kilometers $(2 \mathrm{~km}$ more/less). These sites were chosen over the BSC at Shebeen Alkoom City ( $30^{\circ} 53^{\prime}$ and $30^{\circ} 58^{\prime} \mathrm{N}$ and $31^{\circ} 01^{\prime}$ and $\left.31^{\circ} 02^{\prime} \mathrm{E}\right)$, Menoufia Province, Egypt. The chosen sites were selected to symbolize different contaminated regions (near workshops, hospitals, agricultural fields, refuse centers, etc.). These sampling sites were chosen downstream to all the pollution points. The studied area water's environmental factors were previously mentioned in detail in Khallaf $\boldsymbol{e t ~ a l . ~ ( 2 0 1 8 a ) ' s ~ w o r k . ~ A f t e r ~ c o l l e c t i o n ~ u s i n g ~ E k m a n ~}$ Dredge, the samples were put in dark bags for transportation to the laboratory and preserved frozen until the analyses. The sediment samples were brought to room temperature, dried in air, ground and homogenized in a mortar, and sieved to a fine powder.

\section{Chemical analysis}

$\mathrm{Al}, \mathrm{Cr}$, and $\mathrm{Mn}$ of sediment samples were treated according to Kouadio and Trefry (1987) method. In brief, $0.5 \mathrm{~g}$ of each sample was weighed and into a crucible and digested with a mixture of concentrated $\mathrm{HNO}_{3}+\mathrm{HClO}_{4}+\mathrm{HF}$. After cooling, the digestate was diluted to $50 \mathrm{ml}$ with $\mathrm{HNO}_{3}$. $\mathrm{Al}, \mathrm{Cr}$, and $\mathrm{Mn}$ concentrations were analyzed using Inductive Coupled Plasma-Optical Emission Spectrometry (ICP-AES, Agilent 720). The metal values are expressed as milligrams per kilogram dry weight ( $\mathrm{dw}$ ). Quality control protocols were previously mentioned in detail in the work of Khallaf et al. (2018a). All digestion and the samples' analysis were carried out at the Egyptian Mineral Resources Authority, Ministry of Petroleum, Dokki, Egypt. 


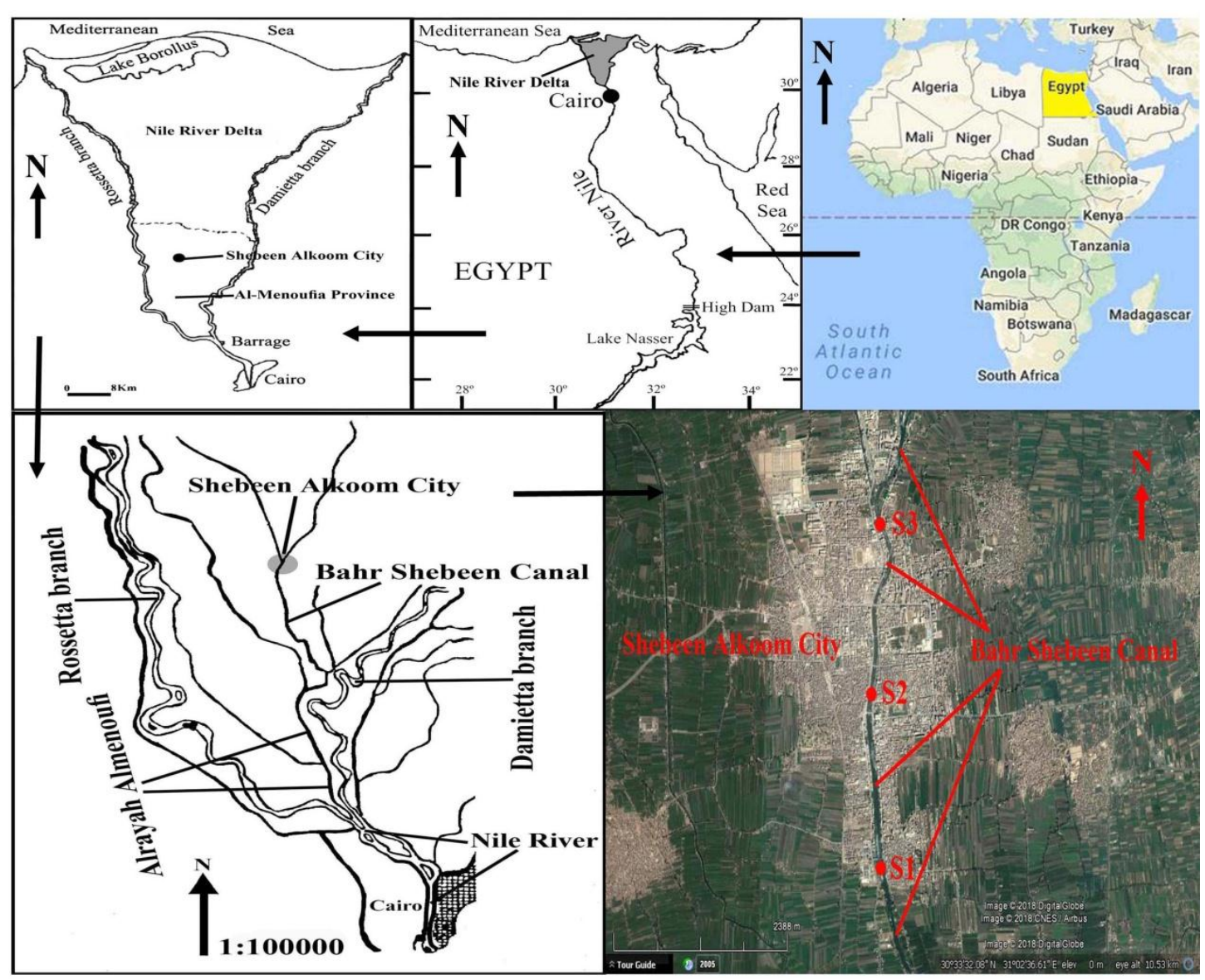

Fig. (1): Map showing the area of study (Bahr Shebeen Canal, BSC, in the Egyptian Delta).

\section{Contamination indices of sediment}

Some pollution indices were used to evaluate the contamination and ecological risk posed by the HMs contamination in sediments. These used indices were classified into two types, single and integrated indices. The descriptive terminologies for contamination classes on single and integrated indices were presented in table (1).

Table (1): The descriptive terminologies for HMs pollution classes on single and integrated indices.

\begin{tabular}{llll}
\hline \multicolumn{2}{l}{ Enrichment Factor $(\mathrm{EF})^{1}$} & \multicolumn{2}{l}{ Contamination Factor $(\mathrm{CF})^{2}$} \\
\hline EF value & Categories & CF value & Pollution \\
\hline $\mathrm{EF}<1$ & No enrichment & $\mathrm{CF}<1$ & Low contamination \\
$1<\mathrm{EF}<3$ & Minor enrichment & $1 \leq \mathrm{CF} \leq 3$ & Moderated contamination \\
$3<\mathrm{EF}<5$ & Moderate enrichment & $3<\mathrm{CF}<6$ & Considerable contamination \\
$5<\mathrm{EF}<10$ & Moderately severe enrichment & $\mathrm{CF} \geq 6$ & Very high contamination \\
$10<\mathrm{EF}<25$ & Severe enrichment & & \\
$25<\mathrm{FE}<50$ & Very severe enrichment & &
\end{tabular}


EF $>50 \quad$ Extremely severe enrichment

\begin{tabular}{|c|c|c|c|c|}
\hline \multicolumn{2}{|c|}{ Potential contamination index $(\mathrm{Cp})^{3}$} & \multicolumn{3}{|c|}{ Geo- accumulation index $\left(I_{g e o}\right)^{4}$} \\
\hline $\mathrm{Cp}$ value & grade & Igeo & Igeo class & Pollution \\
\hline $\mathrm{Cp}<1$ & Low contamination & $<0-0$ & 0 & Unpolluted \\
\hline $1<\mathrm{Cp}<3$ & Moderate contamination & $>0-1$ & 1 & Unpolluted to moderated \\
\hline \multirow[t]{5}{*}{$\mathrm{Cp}>3$} & Severe or very severe contamination & $>1-2$ & 2 & Moderated polluted \\
\hline & & $>2-3$ & 3 & Moderated to high polluted \\
\hline & & $>3-4$ & 4 & Highly polluted \\
\hline & & $>4-5$ & 5 & Highly to extremely polluted \\
\hline & & $>5-6$ & $>5$ & Extremely polluted \\
\hline \multicolumn{2}{|c|}{ potential ecological risk coefficient $\left(\mathrm{E}_{\mathrm{rc}}\right)^{5}$} & \multicolumn{3}{|c|}{ Pollution Load Index (PLI) $^{6}$} \\
\hline $\mathrm{E}_{\mathrm{rc}}$ & grade & \multicolumn{2}{|l|}{ PLI } & Pollution \\
\hline $\mathrm{E}_{\mathrm{rc}}<40$ & Low potential ecological risk & \multicolumn{2}{|l|}{0} & Perfection \\
\hline $40 \leq \mathrm{E}_{\mathrm{rc}}<80$ & Moderate potential ecological risk & \multicolumn{2}{|l|}{$\leq 1$} & Baseline levels \\
\hline $80 \leq \mathrm{E}_{\mathrm{rc}}<160$ & Considerable potential ecological risk & \multicolumn{2}{|l|}{$>1$} & Polluted \\
\hline $160 \leq \mathrm{E}_{\mathrm{rc}}<320$ & High potential ecological risk & & & \\
\hline $\mathrm{E}_{\mathrm{rc}} \geq 320$ & Very high ecological risk & & & \\
\hline \multicolumn{2}{|c|}{ Degree of Contamination (DC) ${ }^{7}$} & \multicolumn{3}{|c|}{ Potential ecological risk index $(\mathrm{RI})^{8}$} \\
\hline $\mathrm{DC}$ & Description & \multicolumn{2}{|l|}{ RI } & grade \\
\hline $\mathrm{DC}<8$ & Low degree of contamination & \multicolumn{2}{|c|}{$\mathrm{RI}<150$} & Low ecological risk \\
\hline $8 \leq \mathrm{DC}<16$ & Moderate degree of contamination & \multicolumn{2}{|c|}{$150 \leq \mathrm{RI}<300$} & Moderate ecological risk \\
\hline $16 \leq \mathrm{DC}<32$ & Considerable degree of contamination & \multicolumn{2}{|c|}{$300 \leq \mathrm{RI}<600$} & Considerable ecological risk \\
\hline $\mathrm{DC} \geq 32$ & Very high degree of contamination & \multicolumn{2}{|c|}{$\mathrm{RI} \geq 600$} & Very high ecological risk \\
\hline
\end{tabular}

${ }^{1}$ Sakan et al. (2009). $\quad{ }^{2}$ Hakanson (1980). $\quad{ }^{3}$ Dauvalter and Rognerud (2001). ${ }^{4}$ Müller (1969). ${ }^{5}$ Hakanson (1980). ${ }^{6}$ Tomlinson et al. (1980). ${ }^{7,8}$ Hakanson (1980).

\subsection{The single indices}

\subsubsection{Enrichment factor $(E F)$}

The EF is used to determine the anthropogenic HMs pollution degree. It is computed by using the Sinex and Helz (1981) equation:

$$
\mathrm{EF}=\frac{(\mathrm{M} / \mathrm{Al})_{\text {banple }}}{(\mathrm{M} / \mathrm{Al})_{\text {backgound }}}
$$


Where, $(\mathrm{M} / \mathrm{Al})_{\text {sample }}$ is the concentration ratio of the studied metal $\mathrm{M}$ to $\mathrm{Al}$ in sediment sample and $(\mathrm{M} / \mathrm{Al})_{\text {background }}$ is their concentration ratio in the selected reference background. For geochemical normalization, $\mathrm{Al}$ was chosen to be the reference background element, in the current study, to minimize grain size effect while assessing metal distribution (Gu $\boldsymbol{e t}$ al., 2013). Average crustal abundance (Taylor, 1964) and average shale values (ASV) (Turekian and Wedepohl, 1961) were frequently used to provide concentrations of elemental background. Because the reference background values of HMs in local BSC sediment during pre-industrial times have not been determined, so, the average shale values (ASV) (Turekian and Wedepohl, 1961), and the Pre-Aswan High Dam concentrations (PAHDC) of the River Nile sediments (Abu Khatita, 2011) were used for the present study as background references (Table 2).

Table (2): Sediment quality guidelines (SQGs) and sediments classification used in the present study.

\begin{tabular}{|c|c|c|c|}
\hline & $\mathrm{Al}$ & $\mathrm{Cr}$ & $\mathrm{Mn}$ \\
\hline \multicolumn{4}{|c|}{ Sediment quality guidelines (SQGs) } \\
\hline Shale standard ${ }^{1}$ & 80000 & 90 & 850 \\
\hline Earth Crust ${ }^{2}$ & 82300 & 100 & 950 \\
\hline PAHDC $^{3}$ & 32206 & 58 & 276 \\
\hline $\mathrm{LEL}^{4}$ & NA & 26 & 460 \\
\hline $\mathrm{TEL}^{4}$ (ISQG) & NA & 37.3 & NA \\
\hline $\mathrm{SEL}^{4}$ & NA & 110 & 1110 \\
\hline $\mathrm{PEL}^{4}$ & NA & 90 & NA \\
\hline $\mathrm{MET}^{4}$ & NA & 55 & - \\
\hline $\mathrm{ERL}^{4}$ & NA & 80 & NA \\
\hline $\mathrm{ERM}^{4}$ & NA & 145 & NA \\
\hline $\mathrm{TEC}^{4}$ & NA & 56 & 1673 \\
\hline Cons-Based TEC ${ }^{4}$ & NA & 43.4 & NA \\
\hline $\mathrm{PEC}^{4}$ & 58030 & 159 & 1081 \\
\hline Cons-Based PEC ${ }^{4}$ & NA & 111 & NA \\
\hline TET $^{4}$ & NA & 100 & NA \\
\hline \multicolumn{4}{|c|}{ USEPA sediments classification ${ }^{5}$} \\
\hline Non-polluted & - & $<25$ & $<300$ \\
\hline Moderately polluted & - & 25 to 75 & 300 to 500 \\
\hline Heavily polluted & - & $>75$ & $>500$ \\
\hline \multicolumn{4}{|c|}{ NA $=$ not available. PAHDC $=$ Pre Aswan High Dam } \\
\hline
\end{tabular}




\subsubsection{Contamination factor $(C F)$}

$\mathrm{CF}$ is the ratio of the metal content in the studied sediment to the background level of the same metal and obtained (Hakanson, 1980) by the following equation:

$$
\mathrm{CF}=\frac{\mathrm{M}_{\mathrm{x}}}{\mathrm{M}_{\mathrm{b}}}
$$

Where $M_{x}$ is the concentration of the metal in the sample, and $M_{b}$ is its content in the designated background reference.

\subsubsection{The potential contamination index $(\mathrm{Cp})$}

Cp was introduced by Dauvalter and Rognerud (2001) as follows:

$$
\mathrm{Cp}=\frac{(\text { Metal })_{\text {Samplemax }}}{(\text { Metal })_{\text {Background }}}
$$

Where: (Metal) Sample max is the maximum metal concentration in the sediment sample and $(\text { Metal) })_{\text {Background }}$ is the same metal average value in a background reference.

\subsubsection{Geo-accumulation index $\left(I_{\text {geo }}\right)$}

$I_{\text {geo }}$ has been applied to the assessment of any metal contamination in sediment by comparing its current concentration with its pre-industrial level. In the present work, $I_{\text {geo }}$ values were calculated (Müller, 1969) as follows:

$$
\text { Igeo }=\log _{2}\left(\frac{\mathrm{C}_{\mathrm{n}}}{1.5 \mathrm{~B}_{\mathrm{n}}}\right)
$$

Where: $C_{n}$ is the content of any studied metal (n) in the sample and $B_{n}$ is its geochemical background reference value in pre-industrial (pre-civilization) reference [ASV (Turekian and Wedepohl, 1961) and PAHDC (Abu Khatita, 2011)]. Factor 1.5 is introduced to reduce probable variations in the background values that are because of the lithogenic effects, besides the very small anthropogenic influences (Qingjie et al., 2008).

\subsubsection{The potential ecological risk factor of a single heavy metal $\left(E_{r}\right)$}

$\mathrm{E}_{\mathrm{r}}$ can be computed (Hakanson, 1980) via the following equations:

$$
\mathrm{E}_{\mathrm{r}}=\mathrm{T}_{\mathrm{r}} \text { X CF }
$$

Where: $\mathrm{CF}$ is a single element contamination factor, and $\mathrm{T}_{\mathrm{r}}$ is the same element toxic response factor, which represents the requirements of environmental toxicity and sensitivity. $\mathrm{The} \mathrm{Cr}$ and $\mathrm{Mn}$ toxic response factors were 2 and 1, respectively (Hakanson, 1980; Xu et al., 2008).

\subsection{The integrated indices}

\subsubsection{The pollution load index (PLI)}

PLI suggested by Tomlinson et al. (1980) is a comparative mean for evaluating the HMs pollution level between different sites and times. It is given in the following equation:

$$
\mathrm{PLI}=(\mathrm{CF} 1 * \mathrm{CF} 2 * \mathrm{CF} 3 * \ldots \mathrm{CFn})^{1 / \mathrm{n}}
$$

Where $\mathrm{n}$ is the number of the metal ( 3 here), and CF is each single metal contamination factor. 


\subsubsection{The degree of contamination (DC)}

DC for a specified site is the summation of its all contamination factors. It is computed (Hakanson, 1980) as follows:

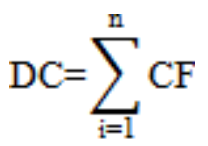

Where CF is the single contamination factor and $\mathrm{n}$ is the number of the metal.

\subsubsection{The potential ecological risk index (RI)}

RI is a method proposed, from a sedimentological perspective, by Hakanson (1980) to evaluate the environmental behaviour and characteristics of HMs contaminants in sediments. It is computed as the summation of all potential ecological risk factors $\left(E_{r}\right)$ for HMs in sediment as follows:

$$
\mathrm{RI}=\sum_{\mathrm{i}=1}^{\mathrm{n}} \mathrm{E}_{\mathrm{s}}
$$

Where: $E_{r}=$ the potential ecological risk factor of a single element and $n$ is metals number.

\section{Sediment quality guidelines (SQGs) and sediment classification}

SQGs assist in expecting the contaminated sediments antagonistic biological influences on aquatic organisms and are purposed for the sediment quality clarification (Long et al., 1995; MacDonald $\boldsymbol{e t}$ al., 2000; Maanan et al., 2015). The dependability of the TEC (threshold effect concentration), Cons-TEC (consensus-based threshold effect concentrations), PEC (probable effect concentration), Cons-PEC (consensus-based probable effect concentrations), LEL (lowest effect level), TEL (threshold effect level), ERL (effect range low), MET (minimal effect threshold), SEL (severe effect level), PEL (probable effect level), ERM (effect range-median) and TET (Toxic effect threshold) (Table 2) for assessing sediment quality conditions is determined based on their predictive ability (Persaud $\boldsymbol{e t}$ al., 1993; MacDonald et al., 2000). USEPA has characterized three sediment evaluations (Giesy and Hoke, 1990), in which the concentration of definite HMs is regarded as factors used to classify the quality of sediments (Table 2).

\section{Human health risk assessment of intake of HMs through dermal contact pathway}

There is a sub-human population exposes directly to the sediments during fisheries, agriculture and other activities (Mahmoud et al., 2017). HMs dermal contact from contaminated aquatic sediments has extraordinary significance in probable exposure pathways (Proshad et al., 2019). CDI $_{\text {dermal-sediment }}$ (Chronic daily intake via dermal contact) is properly evaluated using site-specific data for the population at danger. The evaluating of HMs absorption by dermal contact exposure way of metals in the sediments (USEPA, 2007; Qing et al., 2015), is calculated by this next mathematical equation:

$$
\mathrm{CDI}_{\text {dermal-sediment }}=\frac{\text { CS X SAX AF X ABS X EF XED }}{\text { BWX XI }} \times \text { CF }
$$


Where: $\mathrm{CDI}_{\text {dermal-sediment }}$ is $\mathrm{HMs}$ chronic daily intake $\left(\mathrm{mg} \mathrm{kg}^{-1}\right)$ from sediment by dermal contact. Other values and factors of exposure mentioned in the above equation in the current study are listed and explained in table (3).

Also, current work assessed the non-carcinogenic and carcinogenic influences of HMs from the dermal exposure to contaminated sediments through the HQ (hazard quotient), HI (hazard index) and CRI (carcinogenic risk index) methods (Chabukdhara and Nema, 2013; Wei et al., 2015).

The HQ is expressed by the ratio of the CDI to RfD (the reference daily dose) for each metal (USEPA, 1989), by the following formula (Qing et al., 2015):

$$
\mathrm{HQ}_{\text {dermal-sediment }}=\frac{\mathrm{EDI}}{\mathrm{RAD}}
$$

Where $\mathrm{RfD}(\mathrm{mg} / \mathrm{kg}$ day) is the maximum absorbed daily dose of a metal via dermal contact, for both children and adults, that is supposed not to lead to an significant hazard of harmful effects to sensitive persons during a life span. The $\mathrm{RfD}_{\text {dermal }}$ for $\mathrm{Al}, \mathrm{Cr}$, and $\mathrm{Mn}$ were 1.00E-01, 6.00E-05 and 1.84E-03 mg/kg/day, respectively (USEPA, 2002; USDOE, 2019). When $\mathrm{CDI}<\mathrm{RfD}$, then $\mathrm{HQ} \leq 1$, so it is believed that no severe human health effects will occur, while if the $\mathrm{CDI}>\mathrm{RfD}$, then $\mathrm{HQ}>1$, so it is possible that severe human health effects will occur (USEPA, 1989; USEPA, 2001).

Table (3): Exposure factors of dermal contact for health risk assessment of HMs in sediments.

\begin{tabular}{llllll}
\hline \multirow{2}{*}{ Factor } & Definition & \multirow{2}{*}{ Unit } & \multicolumn{2}{l}{ Value } & Reference \\
\cline { 5 - 6 } & & & Children & Adults & This study \\
CS & Heavy metal concentration in sediment & $\mathrm{mg} \mathrm{kg}^{-1}$ & & & USEPA (2011) \\
$\mathrm{SA}$ & Exposure skin surface area available for contact & $\mathrm{cm}^{2}$ & 1600 & 5700 & USEPA (2011) \\
$\mathrm{AF}$ & Sediment-to-skin adherence factor & $\mathrm{mg} / \mathrm{cm}^{2}$ & 0.2 & 0.7 & USEPA (2011) \\
$\mathrm{ABF}$ & Dermal absorption factor & - & 0.001 & 0.01 & US \\
$\mathrm{EF}$ & Exposure frequency & days/year & 350 & 350 & USEPA (2011) \\
$\mathrm{ED}$ & Exposure duration & years & 6 & 24 & USEPA (2001) \\
$\mathrm{BW}$ & Average body weight of the exposed individual & $\mathrm{Kg}$ & 15 & 60 & USEPA (1989); \\
$\mathrm{AT}$ & Average time for non-carcinogens & $\mathrm{days}$ & $365 \times \mathrm{ED}$ & $365 \times$ ED & USEPA (2011) \\
$\mathrm{CF}$ & Conversion factor & $\mathrm{kg} / \mathrm{mg}$ & $1 \times 10^{-6}$ & $1 \times 10^{-6}$ & USEPA (2002)
\end{tabular}

The HI could be produced from the HQ values to compute the joint hazard of single HMs in the form of a mixture of pollutants (USEPA, 1989; Qing et al., 2015). HI of dermal exposure way could be computed by the next formula (Qing et al., 2015):

$$
\mathrm{HI}_{\text {dermal-sediment }}=\sum \mathrm{HQ}_{\mathrm{n}}=\mathrm{HQ} \text { element } 1+\mathrm{HQ} \text { element } 2 \ldots \ldots \ldots \text { HQ elements } \mathrm{n}
$$

When $\mathrm{HI}<1$, then it is believed that no hazard of non-carcinogenic influences will happen, while if $\mathrm{HI}>1$, this showed the possibility of harmful health influences, and the possibility increases with the HI values increases.

Carcinogenic risk index (CRI) is considered as the possibility of a person developing any cancer type in the entire life as a result of carcinogenic hazards exposure (Li et al., 2014). CRI is calculated (Qing $\boldsymbol{e t}$ al., 2015) as follows:

$$
\mathrm{CRI}=\Sigma \mathrm{CDI}_{\mathrm{i}} \mathrm{XSF_{ \textrm {i } }}
$$


Where: $\mathrm{SF}$ is the cancer slope factor $(\mathrm{mg} / \mathrm{kg}$-day) of individual metal which represents the possibility of developing cancer per unit exposure level. The values of SF for $\mathrm{Al}$ and $\mathrm{Mn}$ were not available, whereas SF value for $\mathrm{Cr}$ was 4.2E+01 (Qing et al., 2015), so only CRI for $\mathrm{Cr}$ was estimated. If $\mathrm{CRI}<10^{-6}$, so the carcinogenic risk from the sediment to health can be negligible, whereas a CRI above $1 \times 10^{-4}$ is likely to be a high risk of developing cancer in human beings. CRI values in the range from $1 \times 10^{-6}$ to $1 \times 10^{-4}$ indicate an acceptable or tolerable risk to social stability and to human health (Wu et al., 2015).

\section{Statistical analysis}

Basic descriptive statistics of HMs concentrations in sediment were performed to calculate means and standard errors (SE). One-way ANOVA analysis, followed by a post hoc comparison using Duncan's multiple ranges (Duncan, 1955), was applied to determine the variance's position and identify significant differences for all metals. All statistical analyses were done using the computer program of SPSS Inc. (version 17.0 for Windows) at the $P<0.05$ and 0.01 levels of significance, and graphs were plotted with Microsoft Excel 2010.

\section{RESULTS AND DISCUSSION}

\section{Spatial and seasonal concentrations of HMs in the sediments}

Sediments, in addition to water, can be considered as a sensitive indicator during aquatic habitat quality monitoring (Bastami et al., 2015). Contaminants in sediments constitute a hazard to the environment in the following two primary ways: (1) environmental risk to fish-eating and aquatic animals and (2) toxic hazards on terrestrial habitat when the polluted area is dredged and put on land (Khan et al., 2000). The spatial and seasonal $\mathrm{Al}, \mathrm{Cr}$, and $\mathrm{Mn}$ average concentrations in the BSC sediments (Table 4) showed that Al has the highest mean concentrations followed by $\mathrm{Mn}$, whereas $\mathrm{Cr}$ has the lowest mean levels. The comparatively high $\mathrm{Al}$ value of sediments reflects the abundance of this element as a major component of clay minerals (Korium et al., 2006). This is because $\mathrm{Al}$ and $\mathrm{Fe}$ are the most common metals in Earth's crust and is also confirmed with that reported by Abdel-Satar (2005) and Khallaf et al. (2018a) on River Nile and BSC sediment, respectively. Also, Mookherjee (2018) mentioned that $\mathrm{Al}$ in the Earth's crust is the third most plentiful element. The wide ranges of $\mathrm{Al}, \mathrm{Cr}$, and $\mathrm{Mn}$ concentrations at different sites may be ascribed to: (1) the texture and particle size of the sediment, (2) the organic matter content (Anonymous, 1997), (3) the mud percent variations, and (4) the increase in heavy metal-rich urban wastes draining into Nile River (Abdel-Satar, 2005; El-Gamal, 2016). Adding to that, the higher values of $\mathrm{Al}, \mathrm{Cr}$, and $\mathrm{Mn}$ are possibly because of the decay of organic materials, agricultural wastes, fertilizers, insecticides, sewage, and illegal wastewater discharges, where BSC receives variable amounts of municipal wastewaters. It is probably associated with the municipal wastes of the nearby city (Shebeen Alkoom City). Spatially, statistical analysis revealed that concentrations of $\mathrm{Al}, \mathrm{Cr}$, and $\mathrm{Mn}$ showed significant $(P<0.05)$ differences between sites. The relatively significant high levels reflect likely anthropogenic point-source of these elements at these locations (Oyewumi et al., 2017). The coefficients of variation (CVs) showed that $\mathrm{Cr}$ has the highest value, followed by Mn and finally Al, with the CVs of 28.43, 25.70, and $22.97 \%$, respectively. These indicate that the metals total concentrations vary between the three sampling sites (Soliman et al., 2019), which may be caused by anthropogenic inputs of HMs (Huang et al., 2019). It was found that Site S1 showed the Al, Cr, and Mn highest mean 
values (Fig. 2A-C). This is showing that this site is comparatively more polluted with these metals compared to other sampling sites, and this is because the extensive discharging of urban waste drove HMs pollution in surface sediment (Khallaf et al., 2018a; Proshad et al., 2019). The urban activities like household refuse, municipal wastewater, urban runoff, and industrial discharges are the main higher metal input sources at S1. The levels of total HMs contamination at different sites are arranged in Site S1> Site S3 > Site S2 for Al and Mn, whereas for $\mathrm{Cr}$, it is arranged in the order of Site S1> Site S2 > Site S3. Seasonally, only Cr and $\mathrm{Mn}$ concentrations showed a difference $(P<0.05)$ between seasons significantly. The levels of $\mathrm{Al}$ concentrations are arranged in the following order: summer $>$ winter $>$ autumn $>$ spring, whereas the $\mathrm{Cr}$ and $\mathrm{Mn}$ levels are arranged in the following order: winter>autumn> spring>summer (Fig. 2D-F). Previously, Alnenaei and Authman (2010) reported that $\mathrm{Al}$ is released into aquatic ecosystems through the recycled $\mathrm{Al}$ industries emissions and the stations of water purification discharge that contain an enormous amount of Al sulfate (alum), which are used as suspended solid particles coagulant. Also, higher concentrations of Al were detected in some drainage canals water in Menoufia Province, Egypt (Authman, 2008; Authman et al., 2008; 2011), which may finally find its way into BSC. The higher $\mathrm{Cr}$ values during winter attributed to the higher $\mathrm{pH}$ and dissolved oxygen during this period caused the oxidation of $\mathrm{Cr}^{2+}$ to $\mathrm{Cr}^{4+}$ and dissolution from water to sediment. Besides, $\mathrm{Cr}$ can precipitate from water to bottom sediment as carbonate or hydroxide resulted in the increasing $\mathrm{pH}$ value during the winter period (Korium et al., 2006). High $\mathrm{Cr}$ concentration in sediments has been related to industrial wastes (as tanneries and textile factories) and sewage wastewater discharge (Singh et al., 2004; 2010; Mohiuddin et al., 2011) from the towns and villages located within BSC catchment. Vasiliu and Dixon (2018) mentioned that the main human activities that increase chromium concentrations are electro painting and textile, leather, and chemical manufacturing. On the other hand, the low $\mathrm{Cr}$ values recorded in the summer season may be related to the higher water temperature. Consequently, the decreases in dissolved oxygen caused the $\mathrm{Cr}$ release from sediment to overlying water (Korium et al., 2006). High Mn concentration in sediments has been related to cosmetics, medical imaging agents, drycell batteries, paints, and fertilizers (ATSDR, 2012) present in refuse, traffic emissions, and sewage wastewater discharge from the towns and villages located within BSC catchment. The relatively higher Mn values were measured in winter due to Mn's precipitation from water to sediment as carbonate form (Korium et al., 2006). Gerke and Little (2018) reported that $\mathrm{Mn}$ carbonates are insoluble. Besides, higher concentrations of $\mathrm{Cr}$ and $\mathrm{Mn}$ during winter than in summer may be attributed to the water's lower flow in winter, which could help to the HMs accumulation in sediment (Mohiuddin et al., 2011; Islam et al., 2014). Adding to that, the Mn contents lower values during summer due to the dissolution of Mn hydroxides and oxides to the overlying water under low dissolved oxygen values and high water temperatures (Elewa, 1993). The slight increase in $\mathrm{Cr}$ and $\mathrm{Mn}$ concentrations in sediment during the spring period might be ascribed to the direct agricultural and industrial wastes inputs discharging into the River Nile (Osman et al., 2012). 
Table (4): Spatial and seasonal variations of $\mathrm{Al}, \mathrm{Cr}$ and $\mathrm{Mn}$ concentrations $\left(\mathrm{mgkg}^{-1} \mathrm{dw}\right)$ in sediment samples collected from different sites along BSC.

\begin{tabular}{|c|c|c|c|c|c|c|c|c|c|c|c|c|c|c|c|c|c|c|}
\hline \multirow{2}{*}{ Sites } & \multicolumn{6}{|c|}{ Aluminum $(\mathrm{Al})$} & \multicolumn{6}{|c|}{ Chromium (Cr) } & \multicolumn{6}{|c|}{ Manganese (Mn) } \\
\hline & Range & & & Mean & \pm & $\mathrm{SE}$ & Range & & & Mean & \pm & $\mathrm{SE}$ & Range & & & Mean & \pm & SE \\
\hline Site 1 & 52959.800 & - & 82470.000 & 67027.542 & \pm & $1794.092^{b}$ & 86.622 & - & 131.026 & 105.356 & \pm & $2.670^{b}$ & 712.339 & - & 1095.530 & 891.353 & \pm & $28.333^{b}$ \\
\hline Site 2 & 31451.000 & - & 65111.500 & 51033.150 & \pm & $2551.818^{\mathrm{a}}$ & 24.331 & - & 126.350 & 79.051 & \pm & $5.483^{\mathrm{a}}$ & 332.416 & - & 1058.170 & 745.990 & \pm & $44.059^{\mathrm{a}}$ \\
\hline Site 3 & 37051.500 & - & 69262.500 & 53242.795 & \pm & $2598.473^{\mathrm{a}}$ & 49.585 & - & 109.516 & 74.185 & \pm & $4.297^{\mathrm{a}}$ & 566.623 & - & 1223.250 & 886.411 & \pm & $56.225^{\mathrm{b}}$ \\
\hline G. Avg. & 31451.000 & - & 82470.000 & 57268.917 & \pm & 1583.583 & 24.331 & - & 131.026 & 86.719 & \pm & 2.968 & 332.416 & - & 1223.250 & 839.288 & \pm & 25.964 \\
\hline$F$-value & & & & 14.311 & & & & & & 15.221 & & & & & & 3.722 & & \\
\hline Sig. & & & & $0.000 * *$ & & & & & & $0.000 * *$ & & & & & & $0.029 *$ & & \\
\hline \multirow{2}{*}{ Seasons } & \multicolumn{6}{|c|}{ Aluminum $(\mathrm{Al})$} & \multicolumn{6}{|c|}{ Chromium $(\mathrm{Cr})$} & \multicolumn{6}{|c|}{ Manganese (Mn) } \\
\hline & Range & & & Mean & \pm & $\mathrm{SE}$ & Range & & & Mean & \pm & $\mathrm{SE}$ & Range & & & Mean & \pm & $\mathrm{SE}$ \\
\hline Spring & 32447.000 & - & 63102.700 & 47638.567 & \pm & $6429.144^{\mathrm{a}}$ & 65.348 & - & 107.994 & 86.241 & \pm & $9.123^{b}$ & 712.339 & - & 730.215 & 721.941 & \pm & $2.620^{\mathrm{ab}}$ \\
\hline Summer & 31451.000 & - & 82470.000 & 60445.267 & \pm & $7351.102^{\mathrm{b}}$ & 24.331 & - & 103.901 & 62.731 & \pm & $11.359^{\mathrm{a}}$ & 332.416 & - & 1067.130 & 661.776 & \pm & $106.201^{\mathrm{a}}$ \\
\hline Autumn & 37051.500 & - & 76799.000 & 57654.050 & \pm & $1806.029^{\mathrm{ab}}$ & 49.585 & - & 126.350 & 90.203 & \pm & $3.008^{\mathrm{b}}$ & 585.675 & - & 1223.250 & 874.061 & \pm & $29.583^{b}$ \\
\hline Winter & 39617.900 & - & 71488.000 & 58120.594 & \pm & $2465.475^{\mathrm{ab}}$ & 54.214 & - & 131.026 & 91.906 & \pm & $6.274^{\mathrm{b}}$ & 566.623 & - & 1143.190 & 897.613 & \pm & $50.392^{\mathrm{b}}$ \\
\hline G. Avg. & 31451.000 & - & 82470.000 & 57268.917 & \pm & 1583.583 & 24.331 & - & 131.026 & 86.719 & \pm & 2.968 & 332.416 & - & 1223.250 & 839.288 & \pm & 25.964 \\
\hline$F$-value & & & & 1.299 & & & & & & 3.752 & & & & & & 3.791 & & \\
\hline Sig. & & & & $0.282 \dagger$ & & & & & & $0.015^{*}$ & & & & & & $0.014 *$ & & \\
\hline
\end{tabular}

Data are expressed as mean \pm standard error (SE)

Means with the same letter at the same column are not significantly different $(P>0.05)$.

G. Avg. $=$ grand average. $F$-value $=$ ANOVA's $F$-test. Sig. $=$ significance level.

$*$ Significant $(P<0.05)$. **Highly significant $(P<0.01)$. $\dagger$ Insignificant $(P>0.05)$. 


\section{Source variation of HMs in the sediments}

Pearson correlation analysis showed that $\mathrm{Al}$ has a highly significant positive correlation with $\mathrm{Cr}$ and $\mathrm{Mn}$ ( $\mathrm{r}=0.693$ and $0.505, P<0.01$, respectively). Bing et al. (2019) mentioned that $\mathrm{Al}$ contained in clay minerals could adsorb HMs in sediments. Cr showed a highly significant positive correlation with $\mathrm{Mn}(\mathrm{r}=0.592, P<0.01)$. A higher correlation coefficient between the metals may indicate the similar distribution pattern of these metals and/or may reveal the same pollution levels, mostly produce from similar pollution origins (either anthropogenic and geogenic), and also move together (Batayneh $\boldsymbol{e t}$ al., 2015; AlAlimi and Alhudify, 2016; El-Radaideh et al., 2017; Proshad et al., 2019). The overall order of profusion of heavy metals of interest in BSC sediments is $\mathrm{Al}>\mathrm{Mn}>\mathrm{Cr}$ (Fig. 2G).

\section{Contamination assessment and pollution indices of HMs in the sediments}

When compared with the average shale values (ASV) [geochemical background] of HMs (Turekian and Wedepohl, 1961), Earth's Crust (Taylor, 1964) and the PAHDC of the River Nile sediments (Abu Khatita, 2011) (Table 2), it was found that the $\mathrm{Al}, \mathrm{Cr}$, and $\mathrm{Mn}$ concentrations in some BSC sediments samples, in this investigation, were higher than these background references, which indicated the contamination of BSC sediments by these HMs. These findings also suggest that the early stage identifies these metals' anthropogenic pollution to the BSC area. The BSC sediments have higher or lower levels of $\mathrm{Al}, \mathrm{Cr}$, and $\mathrm{Mn}$ concentrations compared (Table 5) with those reported studies of other regions in Egypt. Generally, the estimated levels of metals in the current work were comparatively greater than the previously published articles. Differences between present results and the other literature perhaps originate from variations in the localities geological mining history and domestic and urban activities (Yehia and Sebaee, 2012).

The indices of pollution are used to determine the probable adverse effects intensity that could happen in an ecosystem exposed to contaminant stress (Qingjie et al., 2008). In the current study, pollution indices were calculated based on the background of HMs in ASV (Turekian and Wedepohl, 1961) and the PAHDC of the River Nile sediments (Abu Khatita, 2011). EF (Enrichment factor) is a standardization method commonly applied to classify the portions of metal linked with the sediments (Huang et al., 2014; Proshad et al., 2019). EF is used to distinguish between metals arising from anthropogenic or natural activities (Manoj and Padhy, 2014; Al-Taani et al., 2015). It was found that all metals were in no or minor enrichment at all stations and during different seasons (Tables 6 and 7). Generally, the studied metals average EF in the BSC sediments displayed contamination order of $\mathrm{Mn}>\mathrm{Cr}>\mathrm{Al}$ according to ASV and $\mathrm{Mn}>\mathrm{Al}>\mathrm{Cr}$ according to PAHDC. This is showed that $\mathrm{Mn}$ is the most abundant and enriched metal from anthropogenic activities, which is ascribed to refuse, fertilizer, sewage, and raw agricultural and industrial effluents. Sakan et al. (2009) reported that values of $\mathrm{EF}$ from 0 to 1 show that the metal comes totally from crustal materials or natural processes, while values of EF more than 1 show that the origins are more possibly to be anthropogenic (Maanan et al., 2015). The Cr and Mn EF values, in current work, revealed that EF > 1 indicates their enrichments. This suggests that the studied metals maybe came from non-crustal materials and/or non-natural weathering processes (Gao and Chen, 2012; Islam et al., 2015; Proshad et al., 2019) and were probably originated from human influence (anthropogenic inputs). The contamination factor (CF) determination of HMs is a vital aspect that shows the risk degree of HMs to an ecosystem in relation to its retention time (Wu et al., 2010; Buhari and Ismail, 2016) and to express the contamination 
level (Pekey et al., 2004; Barik et al., 2018). The CF values of all metals, in current work, were in low, moderate, and considerable pollution at all sites and during different seasons (Tables 6 and 7). Generally speaking, CF's values were arranged in descending arrangement of the average as follows: $\mathrm{Mn}>\mathrm{Cr}>\mathrm{Al}$ according to $\mathrm{ASV}$ and $\mathrm{Mn}>\mathrm{Al}>\mathrm{Cr}$ according to PAHDC. The high CF value of HMs shows low retention time and high hazard to the environment (Wu et al., 2010; Buhari and Ismail, 2016). Potential contamination index (Cp) shows that all HMs are at low, moderate, severe and/or very severe contamination levels at sampling sites and during different seasons. All HMs showed different degrees of anthropogenic influence according to the $\mathrm{Cp}$ values of the BSC sediments. Overall $\mathrm{Cp}$ values (Tables 6 and 7) were arranged in descending order of the average as follows: $\mathrm{Mn}>\mathrm{Cr}>\mathrm{Al}$ according to ASV and $\mathrm{Mn}>\mathrm{Al}>\mathrm{Cr}$ according to PAHDC. The geo-accumulation index $\left(I_{g e o}\right)$, suggested by Müller (1969), deals with a common method to calculate the metal concentrations enrichment above background or baseline concentrations level. The $I_{g e o}$ values (Tables 6 and 7) vary according to metal type and spatially inside the BSC. According to the Müller (1969) scales, the negative values of $I_{g e o}$ indicated that the BSC sediment could be described as uncontaminated sediment with the studied metals, with some exceptions. According to the $I_{g e o}$ index, site S1 is the most impacted site with Mn classified as moderately polluted, $\mathrm{Al}$ and $\mathrm{Cr}$ considered unpolluted to moderately polluted. Site S3 comes next with Mn classified as moderately polluted, Al considered unpolluted to moderately polluted, whereas $\mathrm{Cr}$ considered unpolluted. At site S2, Al and $\mathrm{Mn}$ were classified as unpolluted to moderately polluted, whereas $\mathrm{Cr}$ was classified as unpolluted according to the $I_{g e o}$ index. Based on the $I_{\text {geo }}$ values (Tables 6 and 7), the trace metals are arranged in the descending rank of the average as follows: $\mathrm{Mn}>\mathrm{Cr}>\mathrm{Al}$ according to ASV and $\mathrm{Mn}>\mathrm{Al}>\mathrm{Cr}$ according to PAHDC. The potential ecological risk factor $\left(E_{r}\right)$ in the sediments (Tables 6 and 7) indicated that all the $\mathrm{Cr}$ and $\mathrm{Mn}$ mean $\mathrm{E}_{\mathrm{r}}$ values were lower than 40 (i.e., $\mathrm{E}_{\mathrm{r}}<40$ ), which showed low ecological risk (Hakanson, 1980). Based on the $E_{r}$ values, the trace metals are arranged in the next descending rank of the average as follows: $\mathrm{Cr}>\mathrm{Mn}$ according to ASV and $\mathrm{Mn}>\mathrm{Cr}$ according to PAHDC. Seasonally, $\mathrm{E}_{\mathrm{r}}$ values were arranged in descending order: winter> autumn> spring> summer. The DC (degree of contamination) values indicate that the sediments of BSC have a low degree of contamination (Tables 6 and 7) based on Hakanson (1980) scale. DC values were arranged in descending order of the average as follows: $\mathrm{S} 1>\mathrm{S} 3>\mathrm{S} 2$ and winter> autumn $>$ spring $>$ summer. Pollution Load Index (PLI) is a powerful method by which the complete risks of HMs could be assessed (Tomlinson et al., 1980). It also offers to analyzing, process, and conveying relevant ecological data to policy managers, makers, technicians, and the community (Harikumar and Jisha, 2010; Mohiuddin et al., 2010). The PLI can supply some understanding of the aquatic ecosystem quality that influences the residents (Ali et al., 2016). Furthermore, it also gives important data about the area of study pollution status that helps decision-makers make any decision (Suresh et al., 2011). PLI values in different sites showed that Site $S 1$ has the highest value of PLI, which indicates the pollution of this site. S3 comes next and finally S1 with the lowest PLI value. According to PAHDC (Abu Khatita, 2011), the canal's PLI indicated that the BSC sediments are polluted (Tables 6 and 7). PLI values were arranged in descending order of the average as follows: $\mathrm{S} 1>\mathrm{S} 3>\mathrm{S} 2$ and winter> autumn> spring $>$ summer. During different seasons, the three sites were at a low-risk level of pollution where the RI (potential ecological risk index) values were much lower than 150 (Tables 6 and 7) as mentioned by Hakanson (1980). RI values were arranged in descending order of the average as follows: S1>S3>S2 and winter> autumn> spring > summer. 

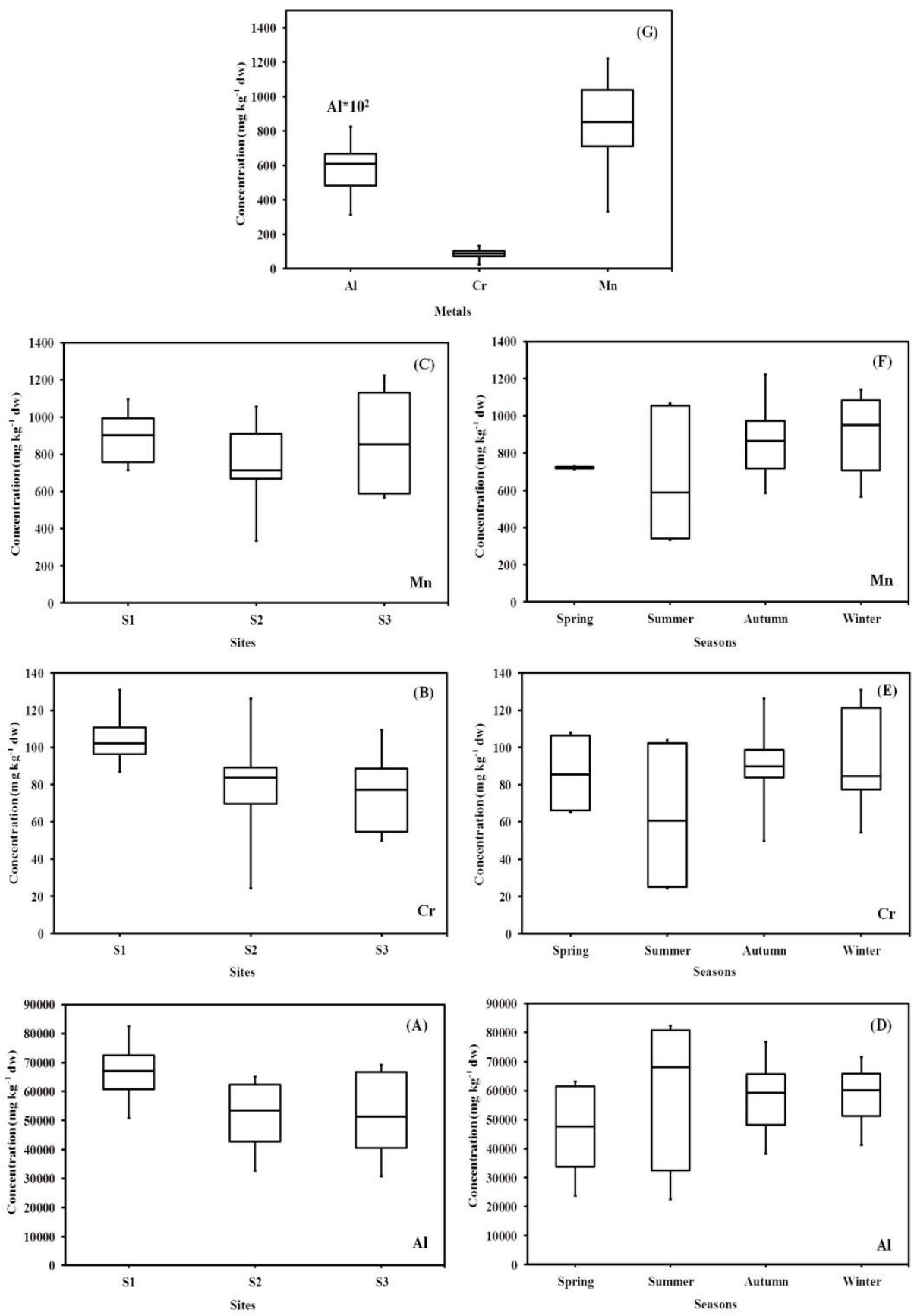

Fig. (2): Box and whisker plots of the spatial (A-C), seasonal (D-F) and total mean variations of $\mathrm{Al}, \mathrm{Cr}$ and $\mathrm{Mn}$ concentrations in sediment of BSC. 
Table (5): Comparison of HMs concentrations $\left(\mathrm{mgkg}^{-1} \mathrm{dw}\right)$ in sediments of BSC with other Egyptian regions.

\begin{tabular}{|c|c|c|c|c|}
\hline Location & $\mathrm{Al}$ & $\mathrm{Cr}$ & $\mathrm{Mn}$ & References \\
\hline $\begin{array}{l}\text { Bahr Shebeen Canal, } \\
\text { Minoufiya governorate }\end{array}$ & $\begin{array}{l}31451- \\
82470\end{array}$ & $\begin{array}{l}24.33- \\
131.03\end{array}$ & $\begin{array}{l}332.42- \\
1223.25\end{array}$ & Present study \\
\hline River Nile at Aswan & $\begin{array}{l}51.73- \\
25716.32\end{array}$ & $\begin{array}{l}44.01- \\
1140.9\end{array}$ & $0.0-2204.01$ & $\begin{array}{l}\text { Korium et al. } \\
(2006)\end{array}$ \\
\hline River Nile at Aswan & - & 8.8 & 210.36 & $\begin{array}{l}\text { Osman and Kloas } \\
(2010)\end{array}$ \\
\hline River Nile at Kena & - & 11.1 & 159.84 & $\begin{array}{l}\text { Osman and Kloas } \\
(\mathbf{2 0 1 0 )}\end{array}$ \\
\hline River Nile at Assiut & - & - & $72.5-98.6$ & $\begin{array}{l}\text { Mekkawy et al. } \\
(2008)\end{array}$ \\
\hline River Nile at Assiut & - & 17.6 & 273.35 & $\begin{array}{l}\text { Osman and Kloas } \\
(2010)\end{array}$ \\
\hline River Nile at Beny-Suef & - & 10.3 & 221.72 & $\begin{array}{l}\text { Osman and Kloas } \\
(\mathbf{2 0 1 0 )}\end{array}$ \\
\hline River Nile at Beny-Suef & - & 15.15 & - & $\begin{array}{l}\text { Mahmoud et al. } \\
\text { (2017) }\end{array}$ \\
\hline $\begin{array}{l}\text { River Nile from Idfo to } \\
\text { Cairo }\end{array}$ & - & - & $94-2425$ & Abdel-Satar (2005) \\
\hline $\begin{array}{l}\text { Nile River at Greater Cairo } \\
\text { district }\end{array}$ & - & $38-46$ & $290-640$ & $\begin{array}{l}\text { Lasheen and } \\
\text { Ammar (2009) }\end{array}$ \\
\hline $\begin{array}{l}\text { Nile Delta Barrage on } \\
\text { Rosetta Branch }\end{array}$ & 12365.5 & 92.50 & 225.19 & $\begin{array}{l}\text { El Bouraie et al. } \\
(2010)\end{array}$ \\
\hline $\begin{array}{l}\text { Rosetta branch of River } \\
\text { Nile }\end{array}$ & - & 8.7 & 269.96 & $\begin{array}{l}\text { Osman and Kloas } \\
(2010)\end{array}$ \\
\hline $\begin{array}{l}\text { Damietta branch of River } \\
\text { Nile }\end{array}$ & - & 9.1 & 351.79 & $\begin{array}{l}\text { Osman and Kloas } \\
(2010)\end{array}$ \\
\hline Lake Nasser & - & 109.4 & 567.57 & Soltan et al. (2005) \\
\hline Lake Nasser & - & 30.79 & 279.6 & Goher et al. (2014) \\
\hline Lake Manzala & $\begin{array}{l}17,348- \\
40,455\end{array}$ & $\begin{array}{l}10.64- \\
44.22\end{array}$ & $295-582$ & Elkady et al. (2015) \\
\hline Lake Qarun & $\begin{array}{l}350.31- \\
671.35\end{array}$ & $\begin{array}{l}54.7- \\
143.31\end{array}$ & - & $\begin{array}{l}\text { Soliman } \\
(\mathbf{2 0 1 8})\end{array}$ \\
\hline Lake El Temsah & - & $\begin{array}{l}12.90- \\
70.84\end{array}$ & $\begin{array}{l}123.56- \\
642.37\end{array}$ & $\begin{array}{l}\text { Soliman } \\
(2019)\end{array}$ \\
\hline
\end{tabular}




\section{Sediment quality guidelines (SQGs) and sediments classification}

SQGs are used to estimate the adverse biological influences of HMs in sediments and give for permissible concentrations of toxic elements to protect the organisms living in or near sediments (MacDonald et al., 2000; Palma $\boldsymbol{e t}$ al., 2015; Wu et al., 2017). The concentrations of $\mathrm{HMs}$ in the collected BSC sediment samples, the current study, were compared with LEL, TEL, TEC, ERL, MET, Cons-Based TEC, SEL, PEL, ERM, TET, PEC, and Cons-Based PEC values (Table 2). Al was higher than PEC in 56.52\% of samples. Cr was greater than LEL, TEL, MET, ERL, TEC, Cons-Based TEC, SEL, PEL, TET, and ConsBased PEC in 95.65, 95.65, 86.96, 68.12, 86.96, 95.65, 13.04, 43.48, 30.43 and $13.04 \%$ of samples, respectively. Mn was higher than LEL, SEL, and PEC in 95.65, 10.15, and 15.94\% of samples, respectively. Based on the SQGs, the adverse impacts on aquatic biota cannot happen when the concentrations of HMs are underneath the TEL, whereas it may occur as the concentrations reach the PEL (Macdonald et al., 1996; Smith et al., 1996). The $\mathrm{Cr}$ concentrations in BSC sediments exceeded the levels of TEL. In their study on sediments of the Beisan River, Tianjin, Qi et al. (2013) proposed Mn values of $460 \mathrm{mg} / \mathrm{kg}$ and 1,100 mg/kg for TEC and PEC, respectively, so these values have been used for current work. In the present study, at all three sampling sites, Mn concentrations in some sediment samples exceed the TEC (Table .2), whereas some sediment samples at site S3 exceed the PEC. According to the USEPA sediments classification (Table 2), generally, it was observed that $4.35 \%$ of the collected sediment samples were non-polluted with $\mathrm{Cr} ; 21.74 \%$ and $4.35 \%$ of samples were moderately-polluted with $\mathrm{Cr}$ and $\mathrm{Mn}$, respectively, while $73.91 \%$ and $95.65 \%$ of sediment samples were heavily polluted with $\mathrm{Cr}$ and $\mathrm{Mn}$, respectively. Present results revealed that the examined metals concentrations might be related to biologically adverse health effects to sediment-dwelling biota (MacDonald et al., 2000).

\section{Human health risk assessment}

The dermal contact of HMs in sediment is regarded as an important exposure pathway. There are many means to expose to metals due to sediment dermal contact as playing, wading, working, etc. (Proshad et al., 2019). The calculated CDI (chronic daily intakes) (Table 8) of the measured metals by dermal contact showed that CDI of $\mathrm{Al}, \mathrm{Cr}$, and Mn was lower than the values of dermal RfD for adult and children at different sites and during different seasons except for $\mathrm{Cr}$ in case of the adult at Site 1. So, there is a probability of developing non-carcinogenic hazard due to dermal exposure of $\mathrm{Cr}$ for the adult at this site. The potential non-carcinogenic lethal influences caused by HMs are commonly distinguished by hazard quotient (HQ) calculation. A glance at table (8) revealed that $\mathrm{Al}, \mathrm{Cr}$, and $\mathrm{Mn}$ have HQ values; as a result of dermal contact; lower than 1 (i.e., $\mathrm{HQ}<1$ ) for adult and children at different sites and during different seasons except for $\mathrm{Cr}$ in case of the adult at Site 1. This proposes that there may be non-carcinogenic adverse health influence to adults via dermal absorption way on over $\mathrm{Cr}$ exposure at this site, indicating non-carcinogenic risk to adults. Due to the exposure to metals and metalloids, the collective effects were computed as HI (hazard index) (Qing et al., 2015). Table (8) showed that the HI values; at different sites and during different seasons; were higher than one (HI>1) for adults, whereas $\mathrm{HI}$ values for children were lower than one $(\mathrm{HI}<1)$. Therefore, there was a possibility of having a noncancer hazard for $\mathrm{Al}, \mathrm{Cr}$, and $\mathrm{Mn}$ on adult health via dermal contact exposure to BSC sediments indicating pose non-cancer risk. In contrast, there was no non-carcinogenic risk for children. 
Table (6): Results of the single and integrated pollution indices of the measured HMs in BSC sediment at different studied sites.

\begin{tabular}{|c|c|c|c|c|c|c|c|c|c|c|c|c|}
\hline \multicolumn{7}{|c|}{ According to ASV (Turekian and Wedepohl, 1961) } & \multicolumn{6}{|c|}{ According to PAHDC of the River Nile sediments (Abu Khatita, 2011) } \\
\hline \multirow[t]{2}{*}{ Sites } & \multicolumn{2}{|l|}{$\mathrm{Al}$} & \multicolumn{2}{|c|}{$\mathrm{Cr}$} & \multicolumn{2}{|l|}{$\mathrm{Mn}$} & \multicolumn{2}{|l|}{$\mathrm{Al}$} & \multicolumn{2}{|c|}{$\mathrm{Cr}$} & \multicolumn{2}{|c|}{$\mathrm{Mn}$} \\
\hline & $\overline{E F}$ & Rank & $\mathrm{EF}$ & Rank & $\overline{\mathrm{EF}}$ & Rank & $\mathrm{EF}$ & Rank & $\mathrm{EF}$ & Rank & $\overline{E F}$ & Rank \\
\hline Site 1 & 1.000 & No enrichment & 1.414 & Minor & 1.255 & Minor & 1.000 & No enrichment & 0.883 & No enrichment & 1.555 & Minor \\
\hline Site 2 & 1.000 & No enrichment & 1.364 & Minor & 1.383 & Minor & 1.000 & No enrichment & 0.852 & No enrichment & 1.714 & Minor \\
\hline Site 3 & 1.000 & No enrichment & 1.260 & Minor & 1.626 & Minor & 1.000 & No enrichment & 0.787 & No enrichment & 2.015 & Minor \\
\hline G. Avg. & 1.000 & No enrichment & 1.350 & Minor & 1.412 & Minor & 1.000 & No enrichment & 0.843 & No enrichment & 1.751 & Minor \\
\hline \multirow[t]{2}{*}{$\begin{array}{l}\text { Sites } \\
\text { sits }\end{array}$} & $\mathrm{Al}$ & & $\mathrm{Cr}$ & & $\mathrm{Mn}$ & & $\mathrm{Al}$ & & $\mathrm{Cr}$ & & $\mathrm{Mn}$ & \\
\hline & $\overline{\mathrm{CF}}$ & Rank & $\overline{C F}$ & Rank & $\overline{\mathrm{CF}}$ & Rank & $\overline{\mathrm{CF}}$ & Rank & $\overline{\mathrm{CF}}$ & Rank & $\mathrm{CF}$ & Rank \\
\hline Site 1 & 0.838 & Low & 1.171 & Moderate & 1.049 & Moderate & 2.081 & Moderate & 1.816 & Moderate & 3.230 & Considerable \\
\hline Site 2 & 0.638 & Low & 0.878 & Low & 0.878 & Low & 1.585 & Moderate & 1.363 & Moderate & 2.703 & Moderate \\
\hline Site 3 & 0.666 & Low & 0.824 & Low & 1.043 & Moderate & 1.653 & Moderate & 1.279 & Moderate & 3.212 & Considerable \\
\hline G. Avg. & 0.716 & Low & 0.964 & Low & 0.987 & Low & 1.778 & Moderate & 1.495 & Moderate & 3.041 & Considerable \\
\hline \multirow[t]{2}{*}{ Sites } & $\mathrm{Al}$ & & $\mathrm{Cr}$ & & $\mathrm{Mn}$ & & $\mathrm{Al}$ & & $\mathrm{Cr}$ & & $\mathrm{Mn}$ & \\
\hline & $\mathrm{Cp}$ & Pollution & $\mathrm{Cp}$ & Pollution & $\mathrm{Cp}$ & Pollution & $\mathrm{Cp}$ & Pollution & $\mathrm{Cp}$ & Pollution & $\mathrm{Cp}$ & Pollution \\
\hline Site 1 & 1.031 & Moderate & 1.456 & Moderate & 1.289 & Moderate & 2.561 & Moderate & 2.259 & Moderate & 3.971 & Severe or very severe \\
\hline Site 2 & 0.814 & Low & 1.404 & Moderate & 1.245 & Moderate & 2.022 & Moderate & 2.172 & Moderate & 3.833 & Severe or very severe \\
\hline Site 3 & 0.866 & Low & 1.217 & Moderate & 1.439 & Moderate & 2.151 & Moderate & 1.897 & Moderate & 4.431 & Severe or very severe \\
\hline G. Avg. & 1.031 & Moderate & 1.456 & Moderate & 1.439 & Moderate & 2.244 & Moderate & 2.109 & Moderate & 4.079 & Severe or very severe \\
\hline \multirow[t]{2}{*}{$\begin{array}{l}\text { Sites } \\
\text { sits }\end{array}$} & $\mathrm{Al}$ & & $\mathrm{Cr}$ & & $\mathrm{Mn}$ & & $\mathrm{Al}$ & & $\mathrm{Cr}$ & & $\mathrm{Mn}$ & \\
\hline & Igeo & Rank & Igeo & Rank & Igeo & Rank & Igeo & Rank & Igeo & Rank & Igeo & Rank \\
\hline Site 1 & -0.852 & Unpolluted & -0.368 & Unpolluted & -0.533 & Unpolluted & 0.460 & Unpolluted to moderated & 0.266 & Unpolluted to moderated & 1.089 & Moderated polluted \\
\hline Site 2 & -1.281 & Unpolluted & -0.888 & Unpolluted & -0.844 & Unpolluted & 0.032 & Unpolluted to moderated & -0.254 & Unpolluted & 0.779 & Unpolluted to moderated \\
\hline Site 3 & -1.208 & Unpolluted & -0.912 & Unpolluted & -0.586 & Unpolluted & 0.105 & Unpolluted to moderated & -0.278 & Unpolluted & 1.037 & Moderated polluted \\
\hline G. Avg. & -1.109 & Unpolluted & -0.714 & Unpolluted & -0.657 & Unpolluted & 0.203 & Unpolluted to moderated & -0.080 & Unpolluted & 0.965 & Unpolluted to moderated \\
\hline \multirow[t]{2}{*}{ Sites } & $\mathrm{Al}$ & & $\mathrm{Cr}$ & & $\mathrm{Mn}$ & & $\mathrm{Al}$ & & $\mathrm{Cr}$ & & $\mathrm{Mn}$ & \\
\hline & Er & Risk grade & Er & Risk grade & Er & Risk grade & Er & Risk grade & Er & Risk grade & Er & Risk grade \\
\hline Site 1 & - & - & 2.341 & Low risk & 1.049 & Low risk & - & - & 3.633 & Low risk & 3.230 & Low risk \\
\hline Site 2 & - & - & 1.757 & Low risk & 0.878 & Low risk & - & - & 2.726 & Low risk & 2.703 & Low risk \\
\hline Site 3 & - & - & 1.649 & Low risk & 1.043 & Low risk & - & - & 2.558 & Low risk & 3.212 & Low risk \\
\hline G. Avg. & - & - & 1.927 & Low risk & 0.987 & Low risk & - & - & 2.990 & Low risk & 3.041 & Low risk \\
\hline \multirow[t]{2}{*}{ Sites } & $\mathrm{DC}$ & & PLI & & RI & & $\mathrm{DC}$ & & PLI & & RI & \\
\hline & value & Grade & value & Grade & value & Grade & value & Grade & value & Grade & value & Grade \\
\hline Site 1 & 3.057 & Low & 1.006 & Polluted & 3.390 & Low risk & 7.127 & Low degree of contamination & 2.294 & Polluted & 6.862 & Low ecological risk \\
\hline Site 2 & 2.394 & Low & 0.783 & Unpolluted & 2.634 & Low risk & 5.650 & Low degree of contamination & 1.786 & Polluted & 5.429 & Low ecological risk \\
\hline Site 3 & 2.533 & Low & 0.821 & Unpolluted & 2.691 & Low risk & 6.144 & Low degree of contamination & 1.873 & Polluted & 5.770 & Low ecological risk \\
\hline G. Avg. & 2.667 & Low & 0.872 & Unpolluted & 2.914 & Low risk & 6.314 & Low degree of contamination & 1.989 & Polluted & 6.031 & Low ecological risk \\
\hline
\end{tabular}

ASV $=$ Average shale values. PAHDC $=$ Pre-Aswan High Dam Concentrations. G. Avg. = grand average. 
Table (7): Results of the single and integrated pollution indices of the measured HMs in BSC sediment during different seasons.

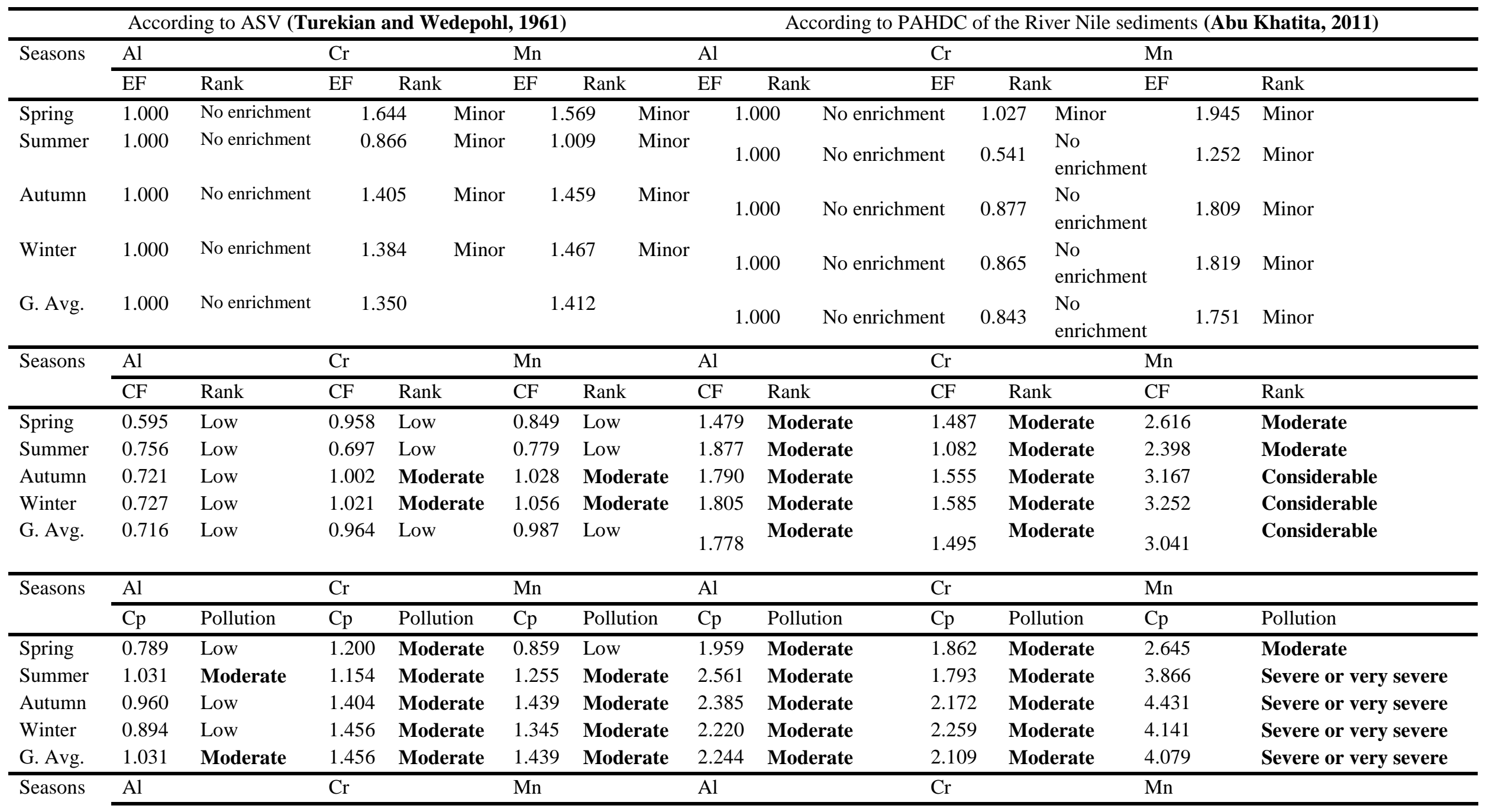




\begin{tabular}{|c|c|c|c|c|c|c|c|c|c|c|c|c|c|}
\hline & Igeo & Rank & Igeo & Rank & Igeo & Rank & Igeo & Rank & Igeo & Rank & Igeo & Rank & \\
\hline Spring & -1.402 & Unpolluted & $\begin{array}{l}- \\
0.688\end{array}$ & Unpolluted & $\begin{array}{l}- \\
0.821\end{array}$ & Unpolluted & $\begin{array}{l}- \\
0.089\end{array}$ & Unpolluted & -0.054 & Unpolluted & 0.802 & $\begin{array}{l}\text { Unpolluted } \\
\text { moderated }\end{array}$ & to \\
\hline Summer & -1.095 & Unpolluted & $\begin{array}{l}- \\
1.335\end{array}$ & Unpolluted & $\begin{array}{l}- \\
1.101\end{array}$ & Unpolluted & 0.218 & $\begin{array}{l}\text { Unpolluted to } \\
\text { moderated }\end{array}$ & -0.701 & Unpolluted & 0.521 & $\begin{array}{l}\text { Unpolluted } \\
\text { moderated }\end{array}$ & to \\
\hline Autumn & -1.084 & Unpolluted & $\begin{array}{l}- \\
0.614\end{array}$ & Unpolluted & $\begin{array}{l}- \\
0.573\end{array}$ & Unpolluted & 0.229 & $\begin{array}{l}\text { Unpolluted to } \\
\text { moderated }\end{array}$ & 0.020 & $\begin{array}{l}\text { Unpolluted to } \\
\text { moderated }\end{array}$ & 1.049 & Moderated polluted & \\
\hline Winter & -1.070 & Unpolluted & $\begin{array}{l}- \\
0.614\end{array}$ & Unpolluted & $\begin{array}{l}- \\
0.549\end{array}$ & Unpolluted & 0.242 & $\begin{array}{l}\text { Unpolluted to } \\
\text { moderated }\end{array}$ & 0.020 & $\begin{array}{l}\text { Unpolluted to } \\
\text { moderated }\end{array}$ & 1.073 & Moderated polluted & \\
\hline G. Avg. & -1.109 & Unpolluted & $\begin{array}{l}- \\
0.714\end{array}$ & Unpolluted & $\begin{array}{l}- \\
0.657\end{array}$ & Unpolluted & 0.203 & $\begin{array}{l}\text { Unpolluted to } \\
\text { moderated }\end{array}$ & -0.080 & Unpolluted & 0.965 & $\begin{array}{l}\text { Unpolluted } \\
\text { moderated }\end{array}$ & to \\
\hline \multirow[t]{2}{*}{ Seasons } & $\mathrm{Al}$ & & $\mathrm{Cr}$ & & $\mathrm{Mn}$ & & $\mathrm{Al}$ & & $\mathrm{Cr}$ & & $\mathrm{Mn}$ & & \\
\hline & $\mathrm{Er}$ & Risk grade & $\mathrm{Er}$ & Risk grade & $\mathrm{Er}$ & Risk grade & $\mathrm{Er}$ & Risk grade & $\mathrm{Er}$ & Risk grade & $\mathrm{Er}$ & Risk grade & \\
\hline Spring & - & - & 1.916 & Low risk & 0.849 & Low risk & - & - & 2.974 & Low risk & 2.616 & Low risk & \\
\hline Summer & - & - & 1.394 & Low risk & 0.779 & Low risk & - & - & 2.163 & Low risk & 2.398 & Low risk & \\
\hline Autumn & - & - & 2.005 & Low risk & 1.028 & Low risk & - & - & 3.110 & Low risk & 3.167 & Low risk & \\
\hline Winter & - & - & 2.042 & Low risk & 1.056 & Low risk & - & - & 3.169 & Low risk & 3.252 & Low risk & \\
\hline G. Avg. & - & - & 1.927 & Low risk & 0.987 & Low risk & - & - & 2.990 & Low risk & 3.041 & Low risk & \\
\hline \multirow[t]{2}{*}{ Seasons } & $\mathrm{DC}$ & & PLI & & RI & & $\mathrm{DC}$ & & PLI & & $\mathrm{RI}$ & & \\
\hline & value & Grade & value & Grade & value & Grade & value & Grade & value & Grade & value & Grade & \\
\hline Spring & 2.403 & Low & 0.779 & Unpolluted & 2.766 & Low risk & 5.582 & $\begin{array}{l}\text { Low degree of } \\
\text { contamination }\end{array}$ & 1.776 & Polluted & 5.590 & Low ecological risk & \\
\hline Summer & 2.231 & Low & 0.739 & Unpolluted & 2.173 & Low risk & 5.356 & $\begin{array}{l}\text { Low degree of } \\
\text { contamination }\end{array}$ & 1.686 & Polluted & 4.561 & Low ecological risk & \\
\hline Autumn & 2.751 & Low & 0.900 & Unpolluted & 3.033 & Low risk & 6.512 & $\begin{array}{l}\text { Low degree of } \\
\text { contamination }\end{array}$ & 2.052 & Polluted & 6.277 & Low ecological risk & \\
\hline Winter & 2.804 & Low & 0.915 & Unpolluted & 3.098 & Low risk & 6.641 & $\begin{array}{l}\text { Low degree of } \\
\text { contamination }\end{array}$ & 2.086 & Polluted & 6.421 & Low ecological risk & \\
\hline G. Avg. & 2.667 & Low & 0.872 & Unpolluted & 2.914 & Low risk & 6.314 & $\begin{array}{l}\text { Low degree of } \\
\text { contamination }\end{array}$ & 1.989 & Polluted & 6.031 & Low ecological risk & \\
\hline
\end{tabular}

ASV $=$ Average shale values. PAHDC $=$ Pre-Aswan High Dam Concentrations. G. Avg. = grand average. 
Table (8): Spatial and seasonal calculated CDI ( $\mathrm{mg} / \mathrm{kg} /$ day), HQ, HI and CRI values of metals from dermal contact in sediment of BSC.

\begin{tabular}{|c|c|c|c|c|c|c|}
\hline & \multicolumn{6}{|l|}{ Metals } \\
\hline & \multicolumn{2}{|c|}{ Aluminium (Al) } & \multicolumn{2}{|c|}{ Chromium $(\mathrm{Cr})$} & \multicolumn{2}{|c|}{ Manganese (Mn) } \\
\hline & Adult & Children & Adult & Children & Adult & Children \\
\hline \multicolumn{7}{|l|}{ CDI } \\
\hline \multicolumn{7}{|l|}{ Sites } \\
\hline Site 1 & 4.27E-02 & $1.37 \mathrm{E}-03$ & $6.72 \mathrm{E}-05$ & $2.16 \mathrm{E}-06$ & $5.68 \mathrm{E}-04$ & $1.82 \mathrm{E}-05$ \\
\hline Site 2 & $3.25 \mathrm{E}-02$ & $1.04 \mathrm{E}-03$ & $5.04 \mathrm{E}-05$ & $1.62 \mathrm{E}-06$ & 4.76E-04 & $1.53 \mathrm{E}-05$ \\
\hline Site 3 & $3.40 \mathrm{E}-02$ & $1.09 \mathrm{E}-03$ & 4.73E-05 & $1.52 \mathrm{E}-06$ & $5.65 \mathrm{E}-04$ & $1.81 \mathrm{E}-05$ \\
\hline G. Avg. & $3.65 \mathrm{E}-02$ & $1.17 \mathrm{E}-03$ & $5.53 \mathrm{E}-05$ & $1.77 \mathrm{E}-06$ & $5.35 \mathrm{E}-04$ & $1.72 \mathrm{E}-05$ \\
\hline \multicolumn{7}{|l|}{ Seasons } \\
\hline Spring & $3.04 \mathrm{E}-02$ & $9.75 \mathrm{E}-04$ & $5.50 \mathrm{E}-05$ & $1.76 \mathrm{E}-06$ & 4.60E-04 & $1.48 \mathrm{E}-05$ \\
\hline Summer & $3.85 \mathrm{E}-02$ & $1.24 \mathrm{E}-03$ & 4.00E-05 & $1.28 \mathrm{E}-06$ & $4.22 \mathrm{E}-04$ & $1.35 \mathrm{E}-05$ \\
\hline Autumn & $3.68 \mathrm{E}-02$ & $1.18 \mathrm{E}-03$ & $5.75 \mathrm{E}-05$ & $1.85 \mathrm{E}-06$ & $5.57 \mathrm{E}-04$ & $1.79 \mathrm{E}-05$ \\
\hline Winter & $3.71 \mathrm{E}-02$ & 1.19E-03 & $5.86 \mathrm{E}-05$ & $1.88 \mathrm{E}-06$ & 5.72E-04 & $1.84 \mathrm{E}-05$ \\
\hline G. Avg. & $3.65 \mathrm{E}-02$ & $1.17 \mathrm{E}-03$ & $5.53 \mathrm{E}-05$ & $1.77 \mathrm{E}-06$ & $5.35 \mathrm{E}-04$ & $1.72 \mathrm{E}-05$ \\
\hline $\mathrm{RfD}_{\text {derm }}$ & $1.00 \mathrm{E}-01$ & & $6.00 \mathrm{E}-05$ & & $1.84 \mathrm{E}-03$ & \\
\hline \multicolumn{7}{|l|}{ HQ } \\
\hline \multicolumn{7}{|l|}{ Sites } \\
\hline Site 1 & 4.27E-01 & $1.37 \mathrm{E}-02$ & $1.12 \mathrm{E}+00$ & $3.59 \mathrm{E}-02$ & $3.09 \mathrm{E}-01$ & 9.91E-03 \\
\hline Site 2 & $3.25 \mathrm{E}-01$ & $1.04 \mathrm{E}-02$ & $8.40 \mathrm{E}-01$ & 2.70E-02 & 2.59E-01 & 8.29E-03 \\
\hline Site 3 & $3.40 \mathrm{E}-01$ & 1.09E-02 & 7.88E-01 & $2.53 \mathrm{E}-02$ & 3.07E-01 & $9.85 \mathrm{E}-03$ \\
\hline G. Avg. & $3.65 \mathrm{E}-01$ & $1.17 \mathrm{E}-02$ & $9.22 \mathrm{E}-01$ & $2.96 \mathrm{E}-02$ & $2.91 \mathrm{E}-01$ & $9.33 \mathrm{E}-03$ \\
\hline \multicolumn{7}{|l|}{ Seasons } \\
\hline Spring & $3.04 \mathrm{E}-01$ & $9.75 \mathrm{E}-03$ & $9.17 \mathrm{E}-01$ & 2.94E-02 & $2.50 \mathrm{E}-01$ & 8.03E-03 \\
\hline Summer & $3.85 \mathrm{E}-01$ & $1.24 \mathrm{E}-02$ & $6.67 \mathrm{E}-01$ & 2.14E-02 & 2.29E-01 & $7.36 \mathrm{E}-03$ \\
\hline Autumn & $3.68 \mathrm{E}-01$ & $1.18 \mathrm{E}-02$ & 9.59E-01 & $3.08 \mathrm{E}-02$ & 3.03E-01 & $9.72 \mathrm{E}-03$ \\
\hline Winter & $3.71 \mathrm{E}-01$ & $1.19 \mathrm{E}-02$ & 9.77E-01 & $3.13 \mathrm{E}-02$ & $3.11 \mathrm{E}-01$ & $9.98 \mathrm{E}-03$ \\
\hline G. Avg. & $3.65 \mathrm{E}-01$ & $1.17 \mathrm{E}-02$ & $9.22 \mathrm{E}-01$ & $2.96 \mathrm{E}-02$ & 2.91E-01 & 9.33E-03 \\
\hline \multicolumn{7}{|l|}{ HI } \\
\hline Sites & Adult & children & Seasons & Adult & children & \\
\hline Site 1 & $1.86 \mathrm{E}+00$ & $5.95 \mathrm{E}-02$ & Spring & $1.47 \mathrm{E}+00$ & 4.72E-02 & \\
\hline Site 2 & $1.42 \mathrm{E}+00$ & $4.57 \mathrm{E}-02$ & Summer & $1.28 \mathrm{E}+00$ & 4.11E-02 & \\
\hline Site 3 & $1.44 \mathrm{E}+00$ & $4.60 \mathrm{E}-02$ & Autumn & $1.63 \mathrm{E}+00$ & $5.23 \mathrm{E}-02$ & \\
\hline \multirow[t]{2}{*}{ G. Avg. } & $1.58 \mathrm{E}+00$ & $5.06 \mathrm{E}-02$ & Winter & $1.66 \mathrm{E}+00$ & 5.32E-02 & \\
\hline & & & G. Avg. & $1.58 \mathrm{E}+00$ & $5.06 \mathrm{E}-02$ & \\
\hline \multicolumn{7}{|c|}{ CRI of $\mathrm{Cr}$} \\
\hline Sites & Adult & children & Seasons & Adult & children & \\
\hline Site 1 & $2.82 \mathrm{E}-03$ & $9.05 \mathrm{E}-05$ & Spring & 2.31E-03 & 7.41E-05 & \\
\hline Site 2 & 2.12E-03 & 6.79E-05 & Summer & $1.68 \mathrm{E}-03$ & 5.39E-05 & \\
\hline Site 3 & $1.99 \mathrm{E}-03$ & 6.37E-05 & Autumn & $2.42 \mathrm{E}-03$ & $7.75 \mathrm{E}-05$ & \\
\hline \multirow[t]{2}{*}{ G. Avg. } & 2.32E-03 & $7.45 \mathrm{E}-05$ & Winter & $2.46 \mathrm{E}-03$ & $7.90 \mathrm{E}-05$ & \\
\hline & & & G. Avg. & 2.32E-03 & $7.45 \mathrm{E}-05$ & \\
\hline
\end{tabular}


HI can serve as a conservative evaluation tool to estimate high-end-risk rather than lowend risk to protect the public (Qu et al., 2012). Paustenbach (2003) and Qing et al. (2015) reported that the chronic non-cancer effect is possible to happen and the possibility increases with the $\mathrm{HI}$ values increase, if the $\mathrm{HI}>1$, whereas, if the value of $\mathrm{HI}<1$, so, no risk of noncarcinogenic effects is believed to occur. By comparing the children's and adult's HI values, it can be deduced that adults have much more chances of non-carcinogenic risk from $\mathrm{Cr}$ in the sediment than children. Carcinogenic risk is considered as the possibility of an individual evolving any kind of cancer in the entire life span as a result of exposure to carcinogenic risks (Li et al., 2014). The carcinogenic risk index (CRI) for dermal contact of exposure; of adults and children; was computed for $\mathrm{Cr}$ (Table 8). The CRI from $\mathrm{Cr}$ at all sites and during different seasons via dermal contact were higher than the target value $1 \times 10^{-6}$ (USEPA, 2011), i.e., were so much higher than the standard value that there could be cancer risk to adult and children in the investigated area. It was reported previously that the chromium, especially $\mathrm{Cr}$ (VI), has been determined to be a human carcinogen for which there is adequate evidence of carcinogenic risk (Wang et al., 2011; Karimi Nezhad et al., 2015).

\section{CONCLUSION}

The present work has shown the presence of higher $\mathrm{Al}, \mathrm{Cr}$, and $\mathrm{Mn}$ concentrations in the BSC sediments, which are obvious anthropogenic activities influences sign within the BSC aquatic environment. Values of the sediment pollution indices may suggest that sediments of BSC are categorized as unpolluted to low/or moderately polluted. Comparing the HMs concentrations in the sediment of BSC with the SQGs and sediment classification grades indicate that there are levels with the potential to impact the ecosystem. Human health risk assessment indices were used to evaluate exposure to HMs from dermal sediments exposure. There is no non-carcinogenic and carcinogenic serious risk for children right now as their health risk indices values are lower than the safe threshold levels. For an adult, the $\mathrm{Cr}$ carcinogenic risk value is higher than the threshold value $\left(1 \mathrm{X}^{-6} 0^{-6}\right)$, indicating that adults are facing $\mathrm{Cr}$ threat. Finally, it is recommended to prohibit the discharges of agricultural runoffs, industrial wastes, and untreated urban and other wastes into the BSC. The present work can help decision-makers with an insightful view on improving the environmental protection strategies of BSC.

\section{Funding}

This research (2014 - 2016) was funded by the University of Minoufiya Research Projects Fund for this article's first author.

\section{REFERENCES}

Abdel-Satar, A.M. (2005). Quality of River Nile sediments from Idfo to Cairo. Egyptian Journal of Aquatic Research, 31(2): 182-199. http://www.niof.sci.eg/images/ejar/vol31/n2/QUALITY\%20OF\%20RIVER\%20NILE\%20SEDIMENTS\%20FROM\%20IDFO\%20TO.pdf

Abu Khatita, A.M. (2011). Assessment of soil and sediment contamination in the Middle Nile Delta area (Egypt)- Geo-Environmental study using combined sedimentological, geophysical and geochemical methods. Faculty of Science, Friedrich-Alexander University, Erlangen-Nürnberg, Germany, 214 p. https://opus4.kobv.de/opus4fau/frontdoor/index/index/docld/1884 
Al-Alimi, A.K.A.A. and Alhudify, N.S. (2016). Assessment of heavy metals contamination and its ecological risk in the surface sediments of al-mukalla coast, Yemen. Journal of Scientific and Engineering Research, 3(3): 13-23. http://jsaer.com/download/vol-3-iss-32016/JSAER2016-03-03-13-23.pdf

Al-Taani, A.A.; Rashdan, M. and Khashashneh, S. (2015). Atmospheric dry deposition of mineral dust to the Gulf of Aqaba, Red Sea: Rate and trace elements. Marine Pollution Bulletin, 92(1): 252-258. https://doi.org/10.1016/j.marpolbul.2014.11.047

Ali, M.M.; Ali, M.L.; Islam, M.S. and Rahman, M.Z. (2016). Preliminary assessment of heavy metals in water and sediment of Karnaphuli River, Bangladesh. Environmental Nanotechnology, Monitoring \& Management, 5: 27-35. https://doi.org/10.1016/ j.enmm.2016.01.002

Alnenaei, A.E. and Authman, M. (2010). Impact of human activities on aluminum contamination in the drainage canals in the Nile Delta, Egypt. Toxicology Letters, 196S: S114, P108-002. https://doi.org/10.1016/i.toxlet.2010.03.403

Anonymous (1997). Investigation of Lake Qarun ecosystem, Final Report submitted to USAID and National Institute of Oceanography and Fisheries (NIOF), Cairo, Egypt, 287 p.

ATSDR (2012). Toxicological profile for manganese. Agency for Toxic Substances and Disease Registry, U.S. Department of Health and Human Services, Public Health Service, Atlanta, GA, 556 p. https://www.atsdr.cdc.gov/ToxProfiles/tp.asp?id=102\&tid=23

Authman, M.M.N. (2008). Oreochromis niloticus as a biomonitor of heavy metal pollution with emphasis on potential risk and relation to some biological aspects. Global Veterenaria, 2(3): 104-109. http://idosi.org/gv/gv2(3)08/3.pdf

Authman, M.M.N. (2011). Environmental and experimental studies of aluminium toxicity on the liver of Oreochromis niloticus (Linnaeus, 1758) fish. Life Science Journal, 8(4): 764-776. http://www.lifesciencesite.com/lsi/life0804/100 7479life0804 764 776.pdf

Authman, M.M.N.; Bayoumy, E.M. and Kenawy, A.M. (2008). Heavy metal concentrations and liver histopathology of Oreochromis niloticus in relation to aquatic pollution. Global Veterenaria, 2(3): 110-116. http://idosi.org/gv/gv2(3)08/4.pdf

Bai, J.; Cui, B.; Chen, B.; Zhang, K.; Deng, W.; Gao, H. and Xiao, R. (2011). Spatial distribution and ecological risk assessment of heavy metals in surface sediments from a typical plateau lake wetland, China. Ecological Modelling, 222(2): 301-306. https://doi.org/10.1016/j.ecolmodel.2009.12.002

Barik, S.K.; Muduli, P.R.; Mohanty, B.; Rath, P. and Samanta, S. (2018). Spatial distribution and potential biological risk of some metals in relation to granulometric content in core sediments from Chilika Lake, India. Environmental Science and Pollution Research, 25(1): 572-587. https://doi.org/10.1007/s11356-017-0421-4

Bastami, K.D.; Afkhami, M.; Mohammadizadeh, M.; Ehsanpour, M.; Chambari, S.; Aghaei, S.; Esmaeilzadeh, M.; Neyestani, M.R.; Lagzaee, F. and Baniamam, M. (2015). Bioaccumulation and ecological risk assessment of heavy metals in the sediments and mullet Liza klunzingeri in the northern part of the Persian Gulf. Marine Pollution Bulletin, 94(1-2): 329-334. https://doi.org/10.1016/i.marpolbul.2015.01.019 
Batayneh, A.T.; Ghrefat, H.; Zumlot, T.; Elawadi, E.; Mogren, S.; Zaman, H.; Al-Taani, A.A.; Nazzal, Y. and Elwahaidi, M. (2015). Assessing of metals and metalloids in surface sediments along the Gulf of Aqaba Coast, Northwestern Saudi Arabia. Journal of Coastal Research, 31(1): 163-176. https://doi.org/10.2112/JCOASTRES-D-13-00143.1

Bibi, M.; Wagreich, M. and lqbal, S. (2020). Trace metals as markers for historical anthropogenic contamination: Evidence from the Peshawar Basin, Pakistan. Science of the Total Environment, 703: 134926. https://doi.org/10.1016/j.scitotenv.2019.134926

Bing, H.; Wu, Y.; Zhou, J.; Sun, H.; Wang, X. and Zhu, H. (2019). Spatial variation of heavy metal contamination in the riparian sediments after two-year flow regulation in the Three Gorges Reservoir, China. Science of The total Environment, 649: 1004-1016. https://doi.org/10.1016/i.scitotenv.2018.08.401

Binning, K. and Baird, D. (2001). Survey of heavy metals in the sediments of the Swartkops River Estuary, Port Elizabeth South Africa. Water SA, 27(4): 461-466. http://dx.doi.org/10.4314/wsa.v27i4.4958

Black, M.C. and Williams, P.L. (2001). Preliminary assessment of metal toxicity in the middle tisza river (Hungary) flood plain. Journal of Soils and Sediments, 1(4): 213-216. https://doi.org/10.1007/BF02987727

Buhari, T.R.I. and Ismail, A. (2016). Heavy Metals Pollution and Ecological Risk Assessment in Surface Sediments of West Coast of Peninsular Malaysia. International Journal of Environmental Science and Development, 7(10): 750-756. https://doi:10.18178/ijesd.2016.7.10.874

CCME (2012). Canadian Sediment Quality Guidelines for the Protection of Aquatic Life. Canadian Council of Ministers of the Environment, December 2012, 9 p. http://probeinternational.org/library/wp-content/uploads/2013/03/CCME-SedimentQuality-Guidelines-for-the-Protection-of-Aquatic-Life-Dec-2012.pdf

Chabukdhara, M. and Nema, A.K. (2013). Heavy metals assessment in urban soil around industrial clusters in Ghaziabad, India: Probabilistic health risk approach. Ecotoxicology and Environmental Safety, 87: 57-64. https://doi.org/10.1016/j.ecoenv.2012.08.032

Dauvalter, V. and Rognerud, S. (2001). Heavy metal pollution in sediments of the Pasvik River drainage. Chemosphere, 42(1): 9-18. https://doi.org/10.1016/S0045-6535(00)00094-1

Davies, C.a.L.; Tomlinson, K. and Stephenson, T. (1991). Heavy metals in river tees estuary sediments. Environmental Technology, 12(11): 961-972. https://doi.org/10.1080/09593339109385095

de Mora, S.; Fowler, S.W.; Wyse, E. and Azemard, S. (2004). Distribution of heavy metals in marine bivalves, fish and coastal sediments in the Gulf and Gulf of Oman. Marine Pollution Bulletin, 49(5): 410-424. https://doi.org/10.1016/j.marpolbul.2004.02.029

Duncan, D.B. (1955). Multiple Range and Multiple $F$ Tests. Biometrics, 11(1): 1-42. https://doi:10.2307/3001478

El-Gamal, A.A. (2016). Sediment and Water Quality of the Nile Delta Estuaries. In: "The Nile Delta. The Handbook of Environmental Chemistry", vol 55. Negm, A.M. (Ed.). Springer International Publishing, Cham, Switzerland, pp. 347-378 https://doi.org/10.1007/698 201647 
El-Radaideh, N.; Al-Taani, A.A. and Al Khateeb, W.M. (2017). Characteristics and quality of reservoir sediments, Mujib Dam, Central Jordan, as a case study. Environmental Monitoring and Assessment, 189(4): 143, 118 p. https://doi.org/10.1007/s10661-017$\underline{5836-3}$

El-Sayed, S.A.; Moussa, E.M.M. and El-Sabagh, M.E.I. (2015). Evaluation of heavy metal content in Qaroun Lake, El-Fayoum, Egypt. Part I: Bottom sediments. Journal of Radiation Research and Applied Sciences, 8(3): 276-285. https://doi.org/10.1016/i.jrras.2015.02.011

El Bouraie, M.M.; El Barbary, A.A.; Yehia, M.M. and Motawea, E.A. (2010). Heavy metal concentrations in surface river water and bed sediments at Nile Delta in Egypt. Suoseura - Finnish Peatland Society, 61(1): 1-12. http://www.suoseura.fi/suo

Elewa, A.S. (1993). Distribution of $\mathrm{Mn}, \mathrm{Cu}, \mathrm{Zn}$, and $\mathrm{Cd}$ in water, sediments and aquatic plants in River Nile and Aswan Reservoir. Egyptian Journal of Applied Science, 8(2): 711-723.

Elkady, A.A.; Sweet, S.T.; Wade, T.L. and Klein, A.G. (2015). Distribution and assessment of heavy metals in the aquatic environment of Lake Manzala, Egypt. Ecological Indicators, 58: 445-457. https://doi.org/10.1016/j.ecolind.2015.05.029

Gao, X. and Chen, C.-T.A. (2012). Heavy metal pollution status in surface sediments of the coastal Bohai Bay. Water Research, 46(6): 1901-1911. https://doi.org/10.1016/ j.watres.2012.01.007

Gerke, T.L. and Little, B.J. (2018). Manganese. In: "Encyclopedia of Geochemistry: A Comprehensive Reference Source on the Chemistry of the Earth". White, W.M. (Ed.). Springer International Publishing, Cham, Switzerland: pp. 864-867. https://doi.org/10.1007/978-3-319-39312-4 119

Giesy, J.P. and Hoke, R.A. (1990). Freshwater Sediment Quality Criteria: Toxicity Bioassessment. In: "Sediments: Chemistry and Toxicity of In-Place Pollutants". Baudo, R.; Giesy, J.P. \& Muntau, H. (Eds.). Lewis Publishers Inc., Ann Arbor, MI, pp. 265-348 http://www.usask.ca/toxicology/igiesy/pdf/publications/BC-029.pdf

Goher, M.E.; Ali, M.H.H. and EI-Sayed, S.M. (2019). Heavy metals contents in Nasser Lake and the Nile River, Egypt: An overview. Egyptian Journal of Aquatic Research, https://doi.org/10.1016/i.ejar.2019.12.002

Goher, M.E.; Farhat, H.I.; Abdo, M.H. and Salem, S.G. (2014). Metal pollution assessment in the surface sediment of Lake Nasser, Egypt. Egyptian Journal of Aquatic Research, 40(3): 213-224. https://doi.org/10.1016/j.ejar.2014.09.004

Gu, J.; Salem, A. and Chen, Z. (2013). Lagoons of the Nile delta, Egypt, heavy metal sink: With a special reference to the Yangtze estuary of China. Estuarine, Coastal and Shelf Science, 117: 282-292. https://doi.org/10.1016/j.ecss.2012.06.012

Hakanson, L. (1980). An ecological risk index for aquatic pollution control. A sedimentological approach. Water Research, 14(8): 975-1001. https://doi.org/10.1016/00431354(80)90143-8

Harikumar, P.S. and Jisha, T.S. (2010). Distribution pattern of trace metal pollutants in the sediments of an urban wetland in the southwest coast of India. International Journal of 
Engineering Science and Technology, 2(5): 840-850. https://www.ijest.info/docs/IJEST10-02-05-40.pdf

Ho, K.C. and Hui, K.C.C. (2001). Chemical contamination of the East River (Dongjiang) and its implication on sustainable development in the Pearl River Delta. Environment International, 26(5): 303-308. https://doi.org/10.1016/S0160-4120(01)00004-6

Huang, B.; Guo, Z.; Xiao, X.; Zeng, P. and Peng, C. (2019). Changes in chemical fractions and ecological risk prediction of heavy metals in estuarine sediments of Chunfeng Lake estuary, China. Marine Pollution Bulletin, 138: 575-583. https://doi.org/10.1016/j.marpolbul.2018.12.015

Huang, P.; Li, T.-G.; Li, A.-C.; Yu, X.-K. and Hu, N.-J. (2014). Distribution, enrichment and sources of heavy metals in surface sediments of the North Yellow Sea. Continental Shelf Research, 73: 1-13. https://doi.org/10.1016/i.csr.2013.11.014

Iqbal, J.; Saleem, M. and Shah, M.H. (2016). Spatial distribution, environmental assessment and source identification of metals content in surface sediments of freshwater reservoir, Pakistan. Chemie der Erde, 76(1): 171-177. https://doi.org/10.1016/j.chemer. 2016.02.002

Islam, M.S.; Ahmed, M.K.; Raknuzzaman, M.; Habibullah-Al-Mamun, M. and Islam, M.K. (2015). Heavy metal pollution in surface water and sediment: A preliminary assessment of an urban river in a developing country. Ecological Indicators, 48: 282-291. https://doi.org/10.1016/j.ecolind.2014.08.016

Islam, M.S.; Han, S.; Ahmed, M.K. and Masunaga, S. (2014). Assessment of Trace Metal Contamination in Water and Sediment of Some Rivers in Bangladesh. Journal of Water and Environment Technology, 12(2): 109-121. https://doi.org/10.2965/jwet.2014.109

Jones, D.S.; Suter Ii, G.W. and Hull, R.N. (1997). Toxicological benchmarks for screening contaminants of potential concern for effects on sediment-associated biota: 1997 Revision. ES/ER/TM-95/R4, Prepared for the U.S. Department of Energy under Contract DE-AC05-84OR21400 by Lockheed Martin Energy Systems, INC., Oak Ridge, TN, 48 p. https://rais.ornl.gov/documents/tm95r4.pdf

Karimi Nezhad, M.T.; Tabatabaii, S.M. and Gholami, A. (2015). Geochemical assessment of steel smelter-impacted urban soils, Ahvaz, Iran. Journal of Geochemical Exploration, 152: 91-109. https://doi.org/10.1016/i.gexplo.2015.02.005

Karthikeyan, R.; Vijayalakshmi, S. and Balasubramanian, T. (2007). Monthly Variation of Heavy Metal and Metal Resistant Bacteria from Uppanar Estuary (South East Coast of India). Research Journal of Microbiology, 2(1): 50-57. https://doi.org/10.3923/jm.2007.50.57

Khallaf, E.A. (2002). An ecological assessment of Bahr Shebeen Nilotic Canal (A Review Paper). Journal of Union of Arab Biologists (Zoology), Cairo, 17(A): 65-75.

Khallaf, E.A.; Authman, M.M.N. and Alne-na-ei, A.A. (2018a). Contamination and Ecological Hazard Assessment of Heavy Metals in Freshwater Sediments and Oreochromis niloticus (Linnaeus, 1758) Fish Muscles in a Nile River Canal in Egypt. Environmental Science and Pollution Research, 25(14): 13796-13812. https://doi.org/10.1007/s11356-018-1521-5

Khallaf, E.A.; Authman, M.M.N. and Alne-na-ei, A.A. (2018b). Evaluation of organochlorine and organophosphorus pesticides residues in the sediment and muscles of Nile tilapia 
Oreochromis niloticus (Linnaeus, 1758) fish from a River Nile Canal, Egypt. International Journal of Environmental Studies, 75(3): 443-465. https://doi.org/10.1080/00207233. $\underline{2017.1378019}$

Khallaf, E.A. and Authman, M.N. (1992). Changes in diet, prey size and feeding habit in Bagrus bayad, and possible interactions with $B$. docmac in a Nile canal. Environmental Biology of Fishes, 34(4): 425-431. https://doi.org/10.1007/bf00004747

Khan, A.G.; Kuek, C.; Chaudhry, T.M.; Khoo, C.S. and Hayes, W.J. (2000). Role of plants, mycorrhizae and phytochelators in heavy metal contaminated land remediation. Chemosphere, 41(1): 197-207. https://doi.org/10.1016/S0045-6535(99)00412-9

Korium, M.A.; Toufeek, M.E.F. and El-Haty, E.Y. (2006). Distribution of Al, Ag, Cr, Mn, Ni, $\mathrm{Zn}$ and some physicochemical characteristics of River Nile water and sediment at Aswan. Egyptian Journal of Aquatic Research, 32(2): 208-225. http://www.niof. sci.eg/images/ejar/vol-32/n2/DISTRIBUTION\%200F\%20AL,\%20AG,\%20CR,\%20MN, \%20NI, \%20ZN\%20AND\%20SOME.pdf

Kouadio, I. and Trefry, J.H. (1987). Sediment trace metal contamination in the Ivory Coast, West Africa. Water, Air, and Soil Pollution, 32(1): 145-154. https://doi.org/10.1007/BF00227690

Lakshmanasenthil, S.; Vinothkumar, T.; Ajithkumar, T.T.; Marudhupandi, T.; Veettil, D.K.; Ganeshamurthy, R.; Ghosh, S. and Balasubramanian, T. (2013). Harmful metals concentration in sediments and fishes of biologically important estuary, Bay of Bengal. Journal of Environmental Health Sciences \& Engineering, 11(1): 33, 37 p. https://doi.org/10.1186/2052-336X-11-33

Lasheen, M.R. and Ammar, N.S. (2009). Speciation of some heavy metals in River Nile sediments, Cairo, Egypt. Environmentalist, 29(1): 8-16. https://doi.org/10.1007/s10669$\underline{008-9175-3}$

Li, Z.; Ma, Z.; Van Der Kuijp, T.J.; Yuan, Z. and Huang, L. (2014). A review of soil heavy metal pollution from mines in China: Pollution and health risk assessment. Science of the Total Environment, 468-469: 843-853. https://doi.org/10.1016/j.scitotenv.2013.08.090

Lin, L.; Li, C.; Yang, W.; Zhao, L.; Liu, M.; Li, Q. and Crittenden, J.C. (2020). Spatial variations and periodic changes in heavy metals in surface water and sediments of the Three Gorges $\begin{array}{llll}\text { Reservoir, China. } & \text { Chemosphere, } & 240 \text { : }\end{array}$ https://doi.org/10.1016/j.chemosphere.2019.124837

Long, E.R.; Macdonald, D.D.; Smith, S.L. and Calder, F.D. (1995). Incidence of adverse biological effects within ranges of chemical concentrations in marine and estuarine sediments. Environmental Management, 19(1): 81-97. https://doi.org/10.1007/BF02472006

Loska, K. and Wiechuła, D. (2003). Application of principal component analysis for the estimation of source of heavy metal contamination in surface sediments from the Rybnik Reservoir. Chemosphere, 51(8): 723-733. https://doi.org/10.1016/S00456535(03)00187-5

Maanan, M.; Saddik, M.; Maanan, M.; Chaibi, M.; Assobhei, O. and Zourarah, B. (2015). Environmental and ecological risk assessment of heavy metals in sediments of Nador 
lagoon, Morocco. Ecological Indicators, 48: 616-626. https://doi.org/10.1016/ j.ecolind.2014.09.034

Macdonald, D.D.; Carr, R.S.; Calder, F.D.; Long, E.R. and Ingersoll, C.G. (1996). Development and evaluation of sediment quality guidelines for Florida coastal waters. Ecotoxicology, 5(4): 253-278. https://doi.org/10.1007/bf00118995

MacDonald, D.D.; Ingersoll, C.G. and Berger, T.A. (2000). Development and Evaluation of Consensus-Based Sediment Quality Guidelines for Freshwater Ecosystems. Archives of Environmental Contamination and Toxicology, 39(1): 20-31. https://doi.org/10.1007/s002440010075

Mahmoud, H.M.; Nassar, H.F.; Hamouda, A.S. and Mabrook, F. (2017). Ecological Risk Assessment of Metals Contaminated Sediments from the Nile River at Beni-Suef Governorate, Egypt. Journal of Applied Life Sciences International, 14(1): 1-11. https://doi.org/10.9734/JALSI/2017/36288

Manoj, K. and Padhy, P.K. (2014). Distribution, enrichment and ecological risk assessment of six elements in bed sediments of a tropical river, Chottanagpur Plateau: A spatial and temporal appraisal. Journal of Environmental Protection, 5(14): 1419-1434. https://doi.org/10.4236/jep.2014.514136

Mekkawy, I.A.A.; Mahmoud, U.M. and Ibrahim, A.T.A. (2008). Heavy metal distribution in some organs of Oreochromis niloticus (Linnaeus, 1758) collected from three localities at Assiut, Egypt and the corresponding tissue damage. Journal of the Egyptian German Society of Zoology, 55(B): 97-127.

Mohiuddin, K.M.; Ogawa, Y.; Zakir, H.M.; Otomo, K. and Shikazono, N. (2011). Heavy metals contamination in water and sediments of an urban river in a developing country. International Journal of Environmental Science \& Technology, 8(4): 723-736. https://doi.org/10.1007/BF03326257

Mohiuddin, K.M.; Zakir, H.M.; Otomo, K.; Sharmin, S. and Shikazono, N. (2010). Geochemical distribution of trace metal pollutants in water and sediments of downstream of an urban river. International Journal of Environmental Science \& Technology, 7(1): 17-28. https://doi.org/10.1007/BF03326113

Mookherjee, M. (2018). Aluminum. In: "Encyclopedia of Geochemistry: A Comprehensive Reference Source on the Chemistry of the Earth". White, W.M. (Ed.). Springer International Publishing, Cham, Switzerland: pp. 27-29. https://doi.org/10.1007/978-3319-39312-4 214

Müller, G. (1969). Index of geo-accumulation in sediments of the Rhine River. Geojournal, 2(3): 108-118.

Muohi, A.W.; Onyari, J.M.; Omondi, J.G. and Mavuti, K.M. (2003). Heavy metals in sediments from Makupa and Port-Reitz Creek systems: Kenyan Coast. Environment International, 28(7): 639-647. https://doi.org/10.1016/S0160-4120(02)00104-6

Osman, A.G.M.; Abuel-Fadl, K.Y.; Elbtar, A.M. and Taha, M.a.M. (2012). Seasonal variations of some heavy metals in water, sediments and fish samples collected from the River Nile, Egypt. Environmental Research Journal, 6(5): 321-328. https://doi.org/10.3923/erj.2012.321.328 
Osman, A.G.M. and Kloas, W. (2010). Water quality and heavy metal monitoring in water, sediments, and tissues of the African Catfish Clarias gariepinus (Burchell, 1822) from the River Nile, Egypt. Journal of Environmental Protection, 1(4): 389-400. https://doi.org/10.4236/iep.2010.14045

Osman, G.Y.; Radwan, N.A.; Khalil, A.I. and Abo Msalam, A.M. (2008). Helminth communities of Bagrus docmac and Malepterurus electricus in three water bodies at Menoufiya Governorate, Egypt. Egyptian Journal of Experimental Biology (Zoology), 4(0): 177-192. http://www.egyseb.net/ejebz/?mno=188917

Oyewumi, O.; Feldman, J. and Gourley, J.R. (2017). Evaluating stream sediment chemistry within an agricultural catchment of Lebanon, Northeastern USA. Environmental Monitoring and Assessment, 189: 141, 115 p. https://doi.org/10.1007/s10661-017$\underline{5856-z}$

Palma, P.; Ledo, L. and Alvarenga, P. (2015). Assessment of trace element pollution and its environmental risk to freshwater sediments influenced by anthropogenic contributions: The case study of Alqueva reservoir (Guadiana Basin). CATENA, 128: 174-184. https://doi.org/10.1016/i.catena.2015.02.002

Paustenbach, D.J. (2003). Human and Ecological Risk Assessment: Theory and Practice. Human and Ecological Risk Assessment, 9(4): 1089-1090. https://doi.org/10.1080/713610025

Pekey, H.; Karakaş, D.; Ayberk, S.; Tolun, L. and Bakoğlu, M. (2004). Ecological risk assessment using trace elements from surface sediments of Izmit Bay (Northeastern Marmara Sea) Turkey. Marine Pollution Bulletin, 48(9): 946-953. https://doi.org/10.1016/i.marpolbul.2003.11.023

Peng, J.-F.; Song, Y.-H.; Yuan, P.; Cui, X.-Y. and Qiu, G.-L. (2009). The remediation of heavy metals contaminated sediment. Journal of Hazardous Materials, 161(2-3): 633-640. https://doi.org/10.1016/i.jhazmat.2008.04.061

Persaud, D.; Jaagumagi, R. and Hayton, A. (1993). Guidelines for the protection and management of aquatic sediment quality in Ontario. Ontario Ministry of Environment and Energy, Ontario, Canada, 39p http://www.itrcweb.org/contsedsbioavailability/References/guide aquatic sed93.pdf

Proshad, R.; Islam, M.S.; Kormoker, T.; Masud, M.E.M. and Ali, M.M. (2018). Assessment of toxic metals contamination with ecological risk of surface water and sediment of Korotoa River in Bangladesh. International Journal of Advanced Geosciences, 6(2): 214221. https://doi.org/10.14419/ijag.v6i2.13742

Proshad, R.; Kormoker, T. and Islam, S. (2019). Distribution, source identification, ecological and health risks of heavy metals in surface sediments of the Rupsa River, Bangladesh. Toxin Reviews: 1-26. https://doi.org/10.1080/15569543.2018.1564143

Qi, W.; Liu, H.; Han, H.; Chai, W. and Qu, J. (2013). A study of metal contamination in sediments in Beisan River System. Acta Scientiae Circumstantiae, 33(1): 117-124. http://caod.oriprobe.com/articles/31317602/A study of metal contamination in sedi ments in Beisan River System.htm

Qing, X.; Yutong, Z. and Shenggao, L. (2015). Assessment of heavy metal pollution and human health risk in urban soils of steel industrial city (Anshan), Liaoning, Northeast China. 
Ecotoxicology and Environmental Safety, 120: 377-385. https://doi.org/10.1016/j.ecoenv.2015.06.019

Qingjie, G.; Jun, D.; Yunchuan, X.; Qingfei, W. and Liqiang, Y. (2008). Calculating Pollution Indices by Heavy Metals in Ecological Geochemistry Assessment and a Case Study in Parks of Beijing. Journal of China University of Geosciences, 19(3): 230-241. https://doi.org/10.1016/S1002-0705(08)60042-4

Qu, C.; Sun, K.; Wang, S.; Huang, L. and Bi, J. (2012). Monte Carlo Simulation-Based Health Risk Assessment of Heavy Metal Soil Pollution: A Case Study in the Qixia Mining Area, China. Human and Ecological Risk Assessment: An International Journal, 18(4): 733-750. https://doi.org/10.1080/10807039.2012.688697

Rodríguez Martín, J.A.; De Arana, C.; Ramos-Miras, J.J.; Gil, C. and Boluda, R. (2015). Impact of 70 years urban growth associated with heavy metal pollution. Environmental Pollution, 196: 156-163. https://doi.org/10.1016/j.envpol.2014.10.014

Sakan, S.M.; Đorđević, D.S.; Manojlović, D.D. and Predrag, P.S. (2009). Assessment of heavy metal pollutants accumulation in the Tisza river sediments. Journal of Environmental Management, 90(11): 3382-3390. https://doi.org/10.1016/i.jenvman.2009.05.013

Shakweer, L.M. and Abbas, M.M. (2005). Effect of ecological and biological factors on the uptake and concentration of trace elements by aquatic organisms at Edku Lake. Egyptian Journal of Aquatic Research, 31(1): 271-287. http://www.niof.sci.eg/images/ejar/vol31/n1/EFFECT\%200F\%20ECOLOGICAL\%20AND\%20BIOLOGICAL\%20FACTORS\%200N\%20 THE\%20UPTAKE\%20AND\%20CONCENTRATION\%20OF\%20TRACE\%20ELEMENTS\%20BY\% 20AQUATIC\%200RGANISMS\%20AT\%20EDKU\%20LAKE.PDF

Sheir, S.K. (2018). Diversity of zooplankton communities at Bahr Shebeen Nilotic canal, ElMenoufia, Egypt: environmental fluctuations or chemical pollution effects? Egyptian Journal of Zoology, 69(69): 175-190. https://doi.org/10.12816/0049669

Sinex, S.A. and Helz, G.R. (1981). Regional geochemistry of trace elements in Chesapeake Bay sediments. Environmental Geology, 3(6): 315-323. https://doi.org/10.1007/BF02473521

Singh, K.P.; Mohan, D.; Sinha, S. and Dalwani, R. (2004). Impact assessment of treated/untreated wastewater toxicants discharged by sewage treatment plants on health, agricultural, and environmental quality in the wastewater disposal area. Chemosphere, 55(2): 227-255. https://doi.org/10.1016/i.chemosphere.2003.10.050

Smith, S.L.; Macdonald, D.D.; Keenleyside, K.A.; Ingersoll, C.G. and Jay Field, L. (1996). A Preliminary Evaluation of Sediment Quality Assessment Values for Freshwater Ecosystems. Journal of Great Lakes Research, 22(3): 624-638. https://doi.org/10.1016/S0380-1330(96)70985-1

Soliman, N.F.; El Zokm, G.M. and Okbah, M.A. (2018). Risk assessment and chemical fractionation of selected elements in surface sediments from Lake Qarun, Egypt using modified BCR technique. Chemosphere, 191: 262-271. https://doi.org/10.1016/ j.chemosphere.2017.10.049

Soliman, N.F.; Younis, A.M. and Elkady, E.M. (2019). An insight into fractionation, toxicity, mobility and source apportionment of metals in sediments from El Temsah Lake, Suez 
Canal. Chemosphere, 222: 165-174.

https://doi.org/10.1016/j.chemosphere.2019.01.009

Soltan, M.E.; Moalla, S.M.N.; Rashed, M.N. and Fawzy, E.M. (2005). Physicochemical characteristics and distribution of some metals in the ecosystem of Lake Nasser, Egypt. Toxicological \& Environmental Chemistry, 87(2): 167-197. https://doi.org/10.1080/ 02772240500043322

Suresh, G.; Ramasamy, V.; Meenakshisundaram, V.; Venkatachalapathy, R. and Ponnusamy, V. (2011). Influence of mineralogical and heavy metal composition on natural radionuclide concentrations in the river sediments. Applied Radiation and Isotopes, 69(10): 14661474. https://doi.org/10.1016/j.apradiso.2011.05.020

Tan, i. and Aslan, E. (2020). Metal pollution status and ecological risk assessment in marine sediments of the inner Izmit Bay. Regional Studies in Marine Science, 33: 100850. https://doi.org/10.1016/j.rsma.2019.100850

Taylor, S.R. (1964). Abundance of chemical elements in the continental crust: a new table. Geochimica et Cosmochimica Acta, 28(8): 1273-1285. https://doi.org/10.1016/00167037(64)90129-2

Tomlinson, D.L.; Wilson, J.G.; Harris, C.R. and Jeffrey, D.W. (1980). Problems in the assessment of heavy-metal levels in estuaries and the formation of a pollution index. Helgoländer Meeresuntersuchungen, 33(1): 566-575. https://doi.org/10.1007/BF02414780

Turekian, K.K. and Wedepohl, K.H. (1961). Distribution of the Elements in Some Major Units of the Earth's Crust. Geological Society of America Bulletin, 72(2): 175-192. https://doi.org/10.1130/0016-7606(1961)72[175:DOTEIS]2.0.CO;2

USDOE (2019). The Risk Assessment Information System (RAIS). Toxicity Profiles. United States Department of Energy. Available from: https://rais.ornl.gov/tox/profiles/Aluminum _ragsa.html; https://rais.ornl.gov/tox/profiles/mn_ragsa.html. Accessed June 2019

USEPA (1989). Risk Assessment Guidance for Superfund. Volume I: Human Health Evaluation Manual (Part A). EPA/540/1-89/002. Interim final. Office of Emergency and Remedial Response, United States Environmental Protection Agency, Washington, D.C. 20450, 291 p. https://www.epa.gov/sites/production/files/2015-09/documents/rags a.pdf

USEPA (2001). Baseline human health risk assessment: Vasquez Boulevard and I-70 Superfund site, Denver, CO. United States Environmental Protection Agency, Region VIII, Denver CO 80202, 170 p. https://nepis.epa.gov/Exe/ZyPDF.cgi/P1006STM.PDF?Dockey =P1006STM. PDF

USEPA (2002). Supplemental Guidance gor Developing Soil Screening Levels for Superfund Sites. OSWER 9355.4-24. Office of Emergency and Remedial Response, United States Environmental Protection Agency, Washington, DC 20460, 187 p. https://nepis.epa.gov/Exe/ZyPDF.cgi/91003IJK.PDF?Dockey=91003IJK.PDF

USEPA (2007). Dermal exposure assessment: A summary of EPA approaches. EPA/600/R07/040F. National Center for Environmental Assessment, Office of Research and Development, United States Environmental Protection Agency, Washington, DC 20460, 59 p. http://ofmpub.epa.gov/eims/eimscomm.getfile?p download id=469581 
USEPA (2011). Exposure Factors Handbook: 2011 Edition (Final Report). EPA/600/R-090/052F. National Center for Environmental Assessment, Office of Research and Development, United States Environmental Protection Agency, Washington, DC 20460, 1466 p. https://www.nrc.gov/docs/ML1400/ML14007A666.pdf

Vasiliu, M. and Dixon, D.A. (2018). Chromium. In: "Encyclopedia of Geochemistry: A Comprehensive Reference Source on the Chemistry of the Earth". White, W.M. (Ed.). Springer International Publishing, Cham, Switzerland: pp. 255-256. https://doi.org/10.1007/978-3-319-39312-4 59

Wang, Z.-X.; Chen, J.-Q.; Chai, L.-Y.; Yang, Z.-H.; Huang, S.-H. and Zheng, Y. (2011). Environmental impact and site-specific human health risks of chromium in the vicinity of a ferro-alloy manufactory, China. Journal of Hazardous Materials, 190(1-3): 980-985. https://doi.org/10.1016/i.jhazmat.2011.04.039

Wei, X.; Gao, B.; Wang, P.; Zhou, H. and Lu, J. (2015). Pollution characteristics and health risk assessment of heavy metals in street dusts from different functional areas in Beijing, China. Ecotoxicology and Environmental Safety, 112: 186-192. https://doi.org/ 10.1016/j.ecoenv.2014.11.005

Wu, P.; Yin, A.; Yang, X.; Zhang, H.; Fan, M. and Gao, C. (2017). Toxic elements in the stream sediments of an urbanized basin, Eastern China: urbanization greatly elevates their adverse biological effects. Environmental Monitoring and Assessment, 189: 167, 113 p. https://doi.org/10.1007/s10661-017-5887-5

Wu, S.; Peng, S.; Zhang, X.; Wu, D.; Luo, W.; Zhang, T.; Zhou, S.; Yang, G.; Wan, H. and Wu, L. (2015). Levels and health risk assessments of heavy metals in urban soils in Dongguan, China. Journal of Geochemical Exploration, 148: 71-78. https://doi.org/ 10.1016/j.gexplo.2014.08.009

Wu, Y.-G.; Xu, Y.-N.; Zhang, J.-H. and Hu, S.-H. (2010). Evaluation of ecological risk and primary empirical research on heavy metals in polluted soil over Xiaoqinling gold mining region, Shaanxi, China. Transactions of Nonferrous Metals Society of China, 20(4): 688-694. https://doi.org/10.1016/S1003-6326(09)60199-0

Xia, F.; Zhang, C.; Qu, L.; Song, Q.; Ji, X.; Mei, K.; Dahlgren, R.A. and Zhang, M. (2020). A comprehensive analysis and source apportionment of metals in riverine sediments of a rural-urban watershed. Journal of Hazardous Materials, 381: 121230. https://doi.org/10.1016/i.jhazmat.2019.121230

Xu, Z.-Q.; Ni, S.-J.; Tuo, X.-G. and Zhang, C.-J. (2008). Calculation of Heavy Metals' Toxicity Coefficient in the Evaluation of Potential Ecological Risk Index. Environmental Science \& Technology, 31(2): 112-115. http://en.cnki.com.cn/Article_en/CJFDTotal-FJKS20080 2029.htm

Yehia, H.M. and Sebaee, E.S. (2012). Bioaccumulation of heavy metals in water, sediment and fish (Oreochromis niloticus and Clarias anguillaris), in Rosetta branch of the River Nile, Egypt. African Journal of Biotechnology, 11(77): 14204-14216. http://dx.doi.org/ 10.5897/AJB11.3745

Yi, Y.; Yang, Z. and Zhang, S. (2011). Ecological risk assessment of heavy metals in sediment and human health risk assessment of heavy metals in fishes in the middle and lower reaches 
of the Yangtze River basin. Environmental Pollution, 159(10): 2575-2585. https://doi.org/10.1016/j.envpol.2011.06.011

Yu, R.; Yuan, X.; Zhao, Y.; Hu, G. and Tu, X. (2008). Heavy metal pollution in intertidal sediments from Quanzhou Bay, China. Journal of Environmental Sciences, 20(6): 664-669. https://doi.org/10.1016/S1001-0742(08)62110-5

Zheng, N.; Wang, Q.; Liang, Z. and Zheng, D. (2008). Characterization of heavy metal concentrations in the sediments of three freshwater rivers in Huludao City, Northeast China. Environmental Pollution, 154(1): 135-142. https://doi.org/10.1016/ j.envpol. 2008.01.001 